Article

\title{
LC-MS-Based Metabolomics for the Chemosystematics of Kenyan Dodonaea viscosa Jacq (Sapindaceae) Populations
}

\author{
Magrate M. Kaigongi ${ }^{1,2, *(\mathbb{D})}$, Catherine W. Lukhoba ${ }^{1}\left(\mathbb{D}\right.$, Purity J. Ochieng $^{3}{ }^{3}$, \\ Malcolm Taylor ${ }^{4}\left(\mathbb{D}\right.$, Abiy Yenesew ${ }^{3}$ (D) and Nokwanda P. Makunga ${ }^{5, *(D)}$ \\ 1 Department of botany, School of Biological Sciences, College of Biological and Physical Sciences, \\ University of Nairobi, Nairobi P.O. Box 30197-00100, Kenya; clukhoba@uonbi.ac.ke \\ 2 Kenya Forestry Research Institute, Nairobi P.O. Box 20412-00200, Kenya \\ 3 Department of Chemistry, School of Physical Sciences, University of Nairobi, \\ Nairobi P.O. Box 30197-00100, Kenya; jaelpurityochieng@gmail.com (P.J.O.); ayenesew@uonbi.ac.ke (A.Y.) \\ 4 Central Analytical Facilities (CAF), Stellenbosch University, JC Smuts Building, Van Der Byl Rd, \\ Stellenbosch Central, Stellenbosch 7600, South Africa; mtaylor@sun.ac.za \\ 5 Department of Botany and Zoology, Stellenbosch University, Private Bag X1, Matieland 7602, South Africa \\ * Correspondence: kaigongim@gmail.com (M.M.K.); makunga@sun.ac.za (N.P.M.); \\ Tel.: +254-729-450-090 (M.M.K.); +27-21-808-3061 (N.P.M.)
}

Academic Editor: Stefano Dall'Acqua

Received: 23 July 2020; Accepted: 2 September 2020; Published: 10 September 2020

check for updates

\begin{abstract}
Dodonaea viscosa Jacq (Sapindaceae) is a medicinal plant with a worldwide distribution. The species has undergone enormous taxonomic changes which caused confusion amongst plant users. In Kenya, for example, two varieties are known to exist based on morphology, i.e., D. viscosa var. viscosa along the coast, and D. viscosa var. angustifolia in the Kenyan inland. These two taxa are recognized as distinct species in some reports. This prompted us to apply metabolomics to understand the relationship among naturally occurring populations of D. viscosa in Kenya, and to identify compounds that can assist in taxonomic delineation of the different varieties of $D$. viscosa from different parts of Kenya. The phytochemical variability of Kenyan D. viscosa var. angustifolia populations collected from four different geographical regions (Nanyuki, Machakos, Nairobi, and Narok) and one coastal D. viscosa var. viscosa (the Gazi) were analyzed by LC-MS using a metabolomics-driven approach. Four known compounds, two diterpenoids (dodonic acid (1), hautriwaic acid lactone (3), and two flavonoids (5,7,4' , 5' -tetrahydroxy-3,6,2' -trimethoxyflavone (2) and catechin (4)) were isolated and purified from the Gazi coastal collection. The presence of these compounds and their relative abundance in other populations was determined by LC-MS analyses. Multivariate statistical analyses of LC-MS data was used for the visualization of the patterns of variation and identification of additional compounds. Eleven discriminant compounds responsible for separating chemometric clusters were tentatively identified. In an antimicrobial assay, hautriwaic acid lactone (3) and catechin (4) were the most active compounds followed by the extract from the coastal (Gazi) population. The clustering pattern of the five populations of $D$. viscosa suggested that the metabolite profiles were influenced by geo-environmental conditions and did not support the current classification of $D$. viscosa based on morphology. This study disputes the current classification of D. viscosa in Kenya and recommends revision using tools such as molecular phylogenetics.
\end{abstract}

Keywords: Dodonaea viscosa; African traditional medicine; antimicrobial activity; chemosystematics; hopbush; metabolomics; natural products chemistry; phenolics; terpenoids 


\section{Introduction}

Dodonaea viscosa Jacq (Sapindaceae) is a globally distributed medicinal plant and its extracts have been shown to have anticancer activity against breast [1] and lung [2] cancer cell lines. The species has well established traditional uses that include treating fever, sore throat, burns, wounds, hemorrhoids, gout, indigestion, ulcers, diarrhea, constipation, trachoma, fractures, rheumatism, malaria, and snake bites [3]. In Ethiopia, the plant has been reported to treat a batch of diseases such as lymphatic swellings and cancer [4]. D. viscosa has also been reported to possess antimicrobial, anti-inflammatory, and antioxidants effects; amongst others [5-7]. Its therapeutic activity is likely associated with the synergistic effect of several constituents [8]. Apart from its medicinal uses, the species is used for construction purposes and as an ornamental plant across the globe [9]. The wide medicinal uses of D. viscosa has led to identification of several phytochemicals. The polyphenolic content and saponins form a substantial fraction of the phytochemical extracts of D. viscosa, making it a species with exceptional bioactivity [9-11].

Harrington and Gadek [12] indicated that D. viscosa was highly variable and studies have mainly used morphological characters to define different subspecies of the taxa. There are seven subspecies recognized in Australia, the place believed to be the center for its evolution, namely D. viscosa subsp. angustifolia, D. viscosa subsp. angustissima, D. viscosa subsp. burmanniana, D. viscosa subsp. cuneata, D. viscosa subsp. mucronata, D. viscosa subsp. spatulate, and D. viscosa subsp. viscosa). Each of these subspecies has a distinct habitat and can handle varying degrees of drought. Major differences that exist among these subspecies are related to growth form, morphological characteristics, and distribution [13].

In Kenya, the following two varieties are recognized: (1) D. viscosa var. viscosa, a thick bush/shrub that grows to 3-4 $\mathrm{m}$ with a fruit capsule that is usually white or brown with two large wings and bisexual flowers. The leaves are somewhat larger than D. viscosa var. angustifolia. This variant is referred to locally as Mkaa pwani (Swahili) and is more confined to the coastal parts of Kenya. (2) D. viscosa var. angustifolia (L.f.) Benth. is a shrub or small tree 1-6 m with pinkish or reddish, two to three winged fruits, and unisexual yellow-green flowers, with a much wider distribution, occurring inland in Kenya [14]. Because the latter is found in many different parts of Kenya, it has many different common names and it is known in local languages as Hidesa (Boran), Kithongoi/Muthongoi (Kamba), Murema muthua (Kikuyu), Muendu (Luhya), Oking' (Luo), Olgeturai/Oltuyesi (Maasai), Tobolokwo (Pokot), Tombolokwa (Sabaot), Msidu (Taita), and Tabilikuet (Tugen) [14,15]. The wide distribution in Kenya has led to distinctive populations being classified as separate species [14], a practice that has further compounded the taxonomy of this taxon. In Kenya, scientific studies have mainly focused on the phytochemistry of D. viscosa var. angustifolia [16]. Despite numerous studies that have provided insights into the pharmacological potential of the plant, no chemical data or biomarkers exist on Kenyan populations to assist with delineation of its biogeographical distribution [17].

Metabolomics approaches have been applied in other species as chemotaxonomic tools because of their high resolution power in providing insights into biogeographic trends, in terms of plant diversification and evolution [18-20]. Furthermore, obtaining metabolomic fingerprints has wide applications in natural product research, with many studies reporting on the use of metabolomic analysis for the quality control of medicinal plants, the manufacturing of phytopharmaceutical products [21-23], and, as part of the drug discovery pipeline where novel bioactive compounds are characterized [24]. The aim of this study was to utilize metabolomics-based chemotaxonomy to solve the existing challenges in the taxonomy of D. viscosa plants found in Kenya (Figure 1 and Table 1) and to determine whether unique chemical markers could be identified. Thereafter, these could be utilized as distinguishing characters that could aid in the botanical classification of this plant. Additionally, isolation of compounds from one of the populations was undertaken with the purpose of generating chemical standards that could be employed as biomarkers to define qualitative and quantitative intraand interpopulation differences. As a proof-of-concept, relative abundance analysis of the purified compounds in the other populations was done. In vitro antimicrobial analysis of these compounds and the extracts from the five populations was conducted using both Gram-positive and -negative 
bacteria and chosen fungi of economic importance to determine the best population in terms of tested antimicrobial activity, as well as to compare the activity of the populations with the isolated compounds.

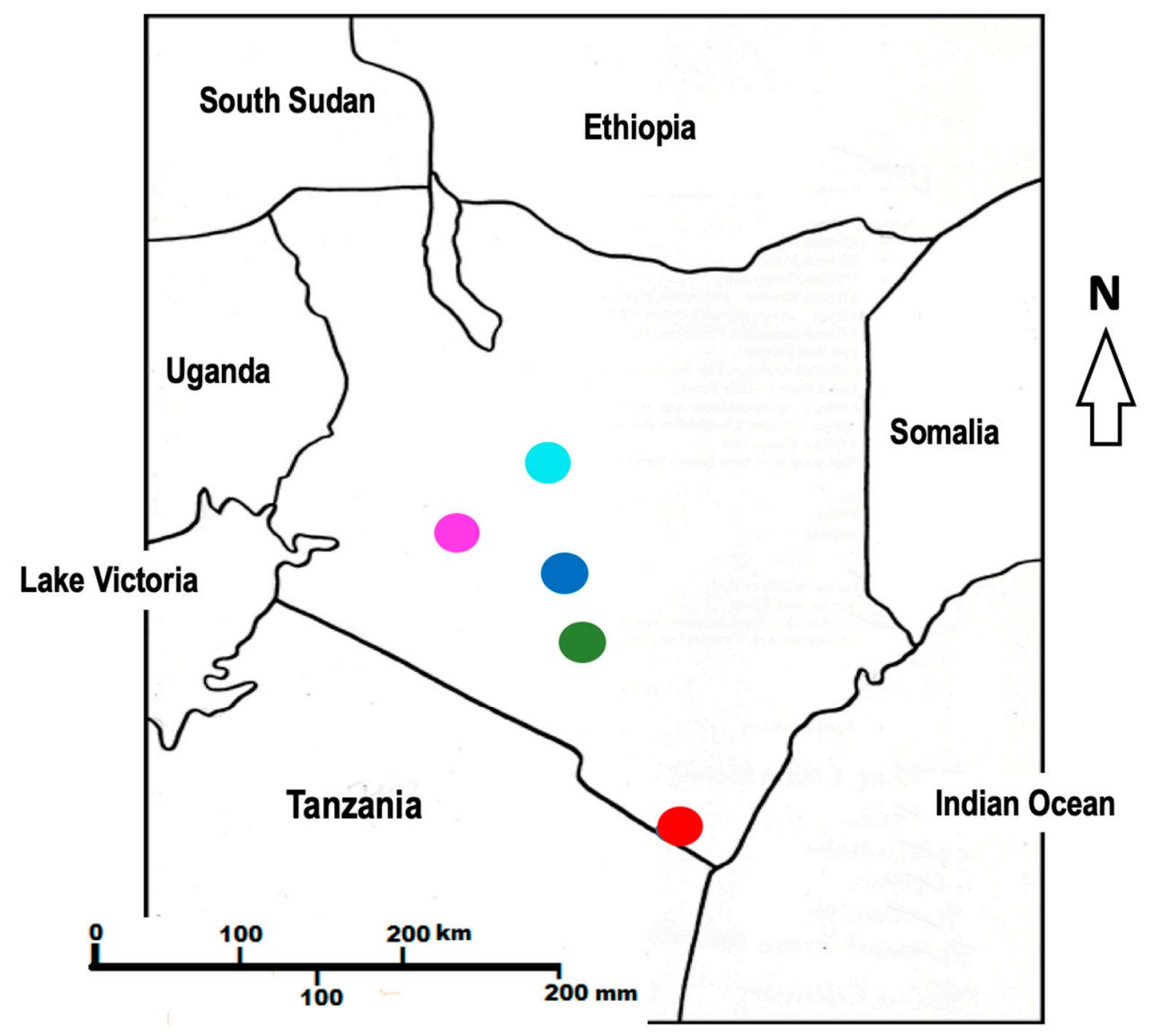

Figure 1. Map of Kenya showing the following sampling points: Gazi coast (red), Machakos (green), Nairobi (blue), Nanyuki (cyan), and Narok (purple).

Table 1. Geographical collections of D. viscosa showing details of specific collections, as well as voucher numbers.

\begin{tabular}{cccccc}
\hline No. & Locality Name & Specific Location & GPS (S) & GPS (E) & Voucher No \\
\hline 1. & Machakos & Kaani ka itheu & $1^{\circ} 29^{\prime} 55.8^{\prime \prime}$ & $37^{\circ} 21^{\prime} 58.2^{\prime \prime}$ & MK2/2018 \\
2. & Nanyuki & Kahurura & $0^{\circ} 02^{\prime} 06.0^{\prime \prime}$ & $37^{\circ} 07^{\prime} 49.4^{\prime \prime}$ & MK4/2018 \\
3. & Coast & Gazi & $4^{\circ} 25^{\prime} 29.1^{\prime \prime}$ & $39^{\circ} 30^{\prime} 22.5^{\prime \prime}$ & MK5/2018 \\
4. & Nairobi & Karura Forest & $1^{\circ} 14^{\prime} 43.6^{\prime \prime}$ & $36^{\circ} 50^{\prime} 17.4^{\prime \prime}$ & MK8/2018 \\
5. & Narok & Maasai Mara Reserve & $1^{\circ} 28^{\prime} 36.5^{\prime \prime}$ & $35^{\circ} 05^{\prime} 33.3^{\prime \prime}$ & MK9/2018 \\
\hline
\end{tabular}

\section{Results and Discussion}

\subsection{Identification of Compounds}

From the extracts, 313 chemicals were present in all the chromatograms assessed, but only 55 compounds were putatively identified and were comprised of phenolics, terpenoids, and saponins, several of which are described here for the first time in D. viscosa (Table 2). Some of the chemicals that were common among the samples include: isorhamnetin, aromadendrin, and chlorogenic acid. The relative abundances of the identified compounds in each population are illustrated in the form of a heat map (Figure 2) in which some compounds are found to be more concentrated (light red in color) in specific populations and less concentrated in other collections (light green in color) with regards to their relative abundances. 
Table 2. List of compounds tentatively identified in D. viscosa showing retention times, detected $[\mathrm{M}-\mathrm{H}]^{-}$ion, elemental composition, MSE fragments, PPM error, and UV absorbance.

\begin{tabular}{|c|c|c|c|c|c|c|c|c|}
\hline & $\begin{array}{l}\text { Experimental } \mathbf{m} / \mathbf{z} \\
{[\mathbf{M}-\mathbf{H}]^{-}}\end{array}$ & $\begin{array}{l}\text { Retention Time } \\
\text { (min) }\end{array}$ & Formula & PPM Error & MSE Fragments & UV (nm) & Proposed Compound & References \\
\hline 1. & 341.1081 & 0.75 & $\mathrm{C}_{21} \mathrm{H}_{25} \mathrm{O}_{4}$ & 1.2 & $\begin{array}{l}341.1078,173.0419 \\
377.0883,515.1646\end{array}$ & weak & Methyl dodovisate B & [25] \\
\hline 2. & 191.0559 & 0.75 & $\mathrm{C}_{10} \mathrm{H}_{7} \mathrm{O}_{4}$ & & $\begin{array}{l}\text { 191.0557, 377.0834, } \\
379.0815,719.1973\end{array}$ & weak & p-Coumaric acid ethyl ester & [26] \\
\hline 3. & 315.0507 & 1.32 & $\mathrm{C}_{16} \mathrm{H}_{12} \mathrm{O}_{7}$ & 0 & $\begin{array}{l}315.0504,300.0272, \\
151.0038,107.0134\end{array}$ & weak & Isorhamnetin & {$[8,17]$} \\
\hline 4. & 315.0711 & 2.41 & $\mathrm{C}_{13} \mathrm{H}_{15} \mathrm{O}_{9}$ & -1.9 & $\begin{array}{c}\text { 315.0612, 153.0178 } \\
109.0285\end{array}$ & weak & Protocatechuic acid 4-O-glucoside & First report * \\
\hline 5. & 315.0718 & 2.41 & $\mathrm{C}_{20} \mathrm{H}_{27} \mathrm{O}_{3}$ & 0.8 & $\begin{array}{l}315.0724,316.0713, \\
327.0630,463.0933\end{array}$ & weak & Hardwickiic acid & [25] \\
\hline 6. & 207.0292 & 2.66 & $\mathrm{C}_{10} \mathrm{H}_{7} \mathrm{O}_{5}$ & -1.4 & $\begin{array}{c}207.0287,163.0394 \\
119.049,165.0393\end{array}$ & 282 & Fraxetin & First report * \\
\hline 7. & 353.0865 & 2.98 & $\mathrm{C}_{16} \mathrm{H}_{17} \mathrm{O}_{9}$ & -2.3 & $\begin{array}{l}353.0872,191.0555 \\
173.0447,119.0487 \\
\end{array}$ & 322 & Chlorogenic acid & First report * \\
\hline 8. & 577.1351 & 3.04 & $\mathrm{C}_{30} \mathrm{H}_{25} \mathrm{O}_{12}$ & 0.9 & $\begin{array}{c}\text { 577.1346, 191.0556, } \\
125.0232,289.071\end{array}$ & 280 & Procyanidin dimer B5 & First report * \\
\hline 9. & 289.0719 & 3.21 & $\mathrm{C}_{15} \mathrm{H}_{13} \mathrm{O}_{6}$ & 1.4 & $\begin{array}{l}289.0715,105.0195 \\
161.0249,267.0509\end{array}$ & 279 & Catechin & [8] \\
\hline 10. & 337.0923 & 3.28 & $\mathrm{C}_{16} \mathrm{H}_{17} \mathrm{O}_{8}$ & -1.2 & $\begin{array}{r}337.0915,173.045, \\
191.0553,289.0701\end{array}$ & 281 & p-Coumaric acid & [9] \\
\hline 11. & 313.0234 & 3.42 & $\mathrm{C}_{20} \mathrm{H}_{25} \mathrm{O}_{3}$ & 1.9 & $\begin{array}{l}313.2361,309.2002 \\
311.2331,311.2128\end{array}$ & 279 & Hautriwaic acid lactone & [25] \\
\hline 12. & 431.1901 & 3.43 & $\mathrm{C}_{27} \mathrm{H}_{27} \mathrm{O}_{5}$ & -6.9 & $\begin{array}{l}382.119,300.0346 \\
153.0962\end{array}$ & weak & $\begin{array}{l}\text { 5,7-Dimethoxy-2,2-dimethyl-10- } \\
\text { (3-methylbut-2-enyl)-8-phenyl-6- } \\
\text { pyrano[3 ,2-g][1]benzopyranone }\end{array}$ & First report * \\
\hline 13. & 609.1458 & 3.7 & $\mathrm{C}_{27} \mathrm{H}_{29} \mathrm{O}_{16}$ & 0.3 & $\begin{array}{l}\text { 609.1367, 301.0345, } \\
300.0277,477.0683\end{array}$ & weak & Rutin & [27] \\
\hline 14. & 593.1502 & 3.9 & $\mathrm{C}_{27} \mathrm{H}_{29} \mathrm{O}_{15}$ & -1.0 & $593.1522,285.0408$ & 351 & Luteolin 7-rutinoside & First report * \\
\hline 15. & 623.1612 & 4.02 & $\mathrm{C}_{28} \mathrm{H}_{31} \mathrm{O}_{16}$ & 1 & $\begin{array}{r}315.0509,300.028 \\
271.0279,243.0317\end{array}$ & weak & $\begin{array}{l}\text { Isorhamnetin 3-O-glucoside } \\
\text { 7-O-rhamnoside }\end{array}$ & First report * \\
\hline
\end{tabular}


Table 2. Cont.

\begin{tabular}{|c|c|c|c|c|c|c|c|c|}
\hline & $\begin{array}{l}\text { Experimental } \mathbf{m} / \mathbf{z} \\
{[\mathbf{M}-\mathbf{H}]^{-}}\end{array}$ & $\begin{array}{l}\text { Retention Time } \\
\text { (min) }\end{array}$ & Formula & PPM Error & MSE Fragments & UV (nm) & Proposed Compound & References \\
\hline 16. & 287.0551 & 4.32 & $\mathrm{C}_{15} \mathrm{H}_{12} \mathrm{O}_{6}$ & -1.9 & $\begin{array}{l}\text { 287.2227, 329.2318, } \\
327.2163,288.2239\end{array}$ & 361 & Aromadendrin & {$[11]$} \\
\hline 17. & 339.1449 & 4.36 & $\mathrm{C}_{17} \mathrm{H}_{23} \mathrm{O}_{7}$ & 2.13 & $\begin{array}{c}287.0554,176.0869 \\
121.0287\end{array}$ & weak & $\begin{array}{l}\text { 3- } \beta \text {-acetoxy-5- } \alpha-(2-\alpha \text {-hydroxyethyl) } \\
\text { acryloyloxy-7-hydroxycarvotacetone }\end{array}$ & First report* \\
\hline 18. & 465.1913 & 4.93 & $\mathrm{C}_{24} \mathrm{H}_{33} \mathrm{O}_{9}$ & 1.09 & $\begin{array}{l}379.1883,285.1477 \\
241.1612,119.0352\end{array}$ & 340 & Terpene lactone 1 & First report* \\
\hline 19. & 931 & 4.95 & $\mathrm{C}_{48} \mathrm{H}_{67} \mathrm{O}_{18}$ & -1.6 & $\begin{array}{l}931,4309,465.212 \\
241.1595,285.1487\end{array}$ & weak & Terpene lactone 1 dimer & First report* \\
\hline 20. & 385.267 & 5.04 & $\mathrm{C}_{21} \mathrm{H}_{37} \mathrm{O}_{6}$ & -0.5 & $\begin{array}{l}385.2659,325.2376 \\
285.1486,177.0921\end{array}$ & weak & Cryptomeridiol-11-rhamnoside & First report* \\
\hline 21. & 361.1647 & 5.46 & $\mathrm{C}_{20} \mathrm{H}_{25} \mathrm{O}_{6}$ & 0.72 & $\begin{array}{c}351.2182,317.17 \\
307.23,243.18,126.03\end{array}$ & 250 & Diterpene lactone & First report * \\
\hline 22. & 351.2171 & 5.48 & $\mathrm{C}_{20} \mathrm{H}_{31} \mathrm{O}_{5}$ & 0.6 & $\begin{array}{l}351.2170,307.2278 \\
315.0502,249.1857\end{array}$ & weak & $\begin{array}{l}\text { ent-16j-Hydroxy-labdan-3a,8b-dihydroxy, } \\
\text { 13(14)-en-15,16-olide }\end{array}$ & [28] \\
\hline 23. & 363.181 & 5.76 & $\mathrm{C}_{20} \mathrm{H}_{27} \mathrm{O}_{6}$ & 0.6 & $\begin{array}{l}363.1711,319.1913 \\
275.201,259.1695\end{array}$ & weak & Terpentecin 1 & First report * \\
\hline 24. & 727.3684 & 5.76 & $\mathrm{C}_{40} \mathrm{H}_{55} \mathrm{O}_{12}$ & -1.4 & $\begin{array}{r}727.3680,363.180 \\
364.1838,275.2008\end{array}$ & weak & Dimer of terpentecin & First report* \\
\hline 25. & 285.0399 & 5.87 & $\mathrm{C}_{15} \mathrm{H}_{9} \mathrm{O}_{6}$ & 0 & $\begin{array}{l}\text { 285.0397, 241.1589, } \\
151.0029,242.162\end{array}$ & 266,366 & Kaempferol & {$[16]$} \\
\hline 26. & 301.0711 & 5.93 & $\mathrm{C}_{15} \mathrm{H}_{9} \mathrm{O}_{7}$ & 3.0 & $\begin{array}{l}301.0700,609.1830 \\
610.1893,302.0850\end{array}$ & 251 & Quercetin & [8] \\
\hline 27. & 315.0021 & 5.97 & $\mathrm{C}_{30} \mathrm{H}_{25} \mathrm{O}_{12}$ & 1.1 & $\begin{array}{l}315.2560,293.2096 \\
316.2598,249.1506\end{array}$ & weak & Quercetin 3'-O-methyl ether & [9] \\
\hline 28. & 363.1807 & 6.12 & $\mathrm{C}_{20} \mathrm{H}_{27} \mathrm{O}_{6}$ & 0.6 & $\begin{array}{c}363.1805,319.1913 \\
275.201,259.1695\end{array}$ & weak & Terpentecin 2 & First report * \\
\hline 29. & 429.2489 & 6.13 & $\mathrm{C}_{23} \mathrm{H}_{26} \mathrm{O}_{8}$ & 2.7 & $\begin{array}{l}429.2496,351.2181 \\
299.0559,285.0429\end{array}$ & 261 & Aliarin & {$[26]$} \\
\hline 30. & 299.0557 & 6.2 & $\mathrm{C}_{16} \mathrm{H}_{11} \mathrm{O}_{6}$ & 1.6 & $\begin{array}{l}299.0557,375.1808 \\
347.1865,300.0591\end{array}$ & weak & Isokaempferide & {$[17,27,29]$} \\
\hline
\end{tabular}


Table 2. Cont

\begin{tabular}{|c|c|c|c|c|c|c|c|c|}
\hline & $\begin{array}{l}\text { Experimental } \mathbf{m} / \mathbf{z} \\
\quad[\mathbf{M}-\mathbf{H}]^{-}\end{array}$ & $\begin{array}{l}\text { Retention Time } \\
\text { (min) }\end{array}$ & Formula & PPM Error & MSE Fragments & UV (nm) & Proposed Compound & References \\
\hline 31. & 327.2164 & 6.3 & $\mathrm{C}_{18} \mathrm{H}_{16} \mathrm{O}_{6}$ & 1.8 & $\begin{array}{l}327.2166,328.2183 \\
325.1966,313.1455\end{array}$ & weak & Kaempferol 5,7,4'-trimethyl ether & [28] \\
\hline 32. & 359.0764 & 6.58 & $\mathrm{C}_{21} \mathrm{H}_{27} \mathrm{O}_{5}$ & 0.8 & $\begin{array}{l}359.0974,266.0666 \\
197.0446,435.1606\end{array}$ & weak & Methoxymkapwanin & [27] \\
\hline 33. & 375.0723 & 6.88 & $\mathrm{C}_{18} \mathrm{H}_{16} \mathrm{O}_{9}$ & 1.6 & $\begin{array}{l}375.0722,361.1641 \\
351.2161,551.2051\end{array}$ & 280 & $\begin{array}{l}5,7,4^{\prime}, 5^{\prime} \text {-Tetrahydroxy-3,6,2'- } \\
\text { trimethoxyflavone }\end{array}$ & First report * \\
\hline 34. & 329.0663 & 7.00 & $\mathrm{C}_{20} \mathrm{H}_{25} \mathrm{O}_{4}$ & 0.2 & $\begin{array}{l}329.0654,361.1648 \\
347.1866,418.2239\end{array}$ & weak & Dodonic acid & [17] \\
\hline 35. & 329.0661 & 7.07 & $\mathrm{C}_{17} \mathrm{H}_{13} \mathrm{O}_{7}$ & 1.5 & $\begin{array}{l}329.0660,271.0249 \\
314.0432,275.2003\end{array}$ & 277,337 & Rhamnazin & {$[17]$} \\
\hline 36. & 375.1808 & 7.13 & $\mathrm{C}_{21} \mathrm{H}_{28} \mathrm{O}_{6}$ & -4.46 & $\begin{array}{c}345.17,319.2,259.17 \\
116.93\end{array}$ & 280 & Terpene lactone 1 & First report * \\
\hline 37. & 343.0822 & 7.43 & $\mathrm{C}_{18} \mathrm{H}_{15} \mathrm{O}_{7}$ & -1.3 & $\begin{array}{l}343.0817,344.0853 \\
393.1919,345.1689\end{array}$ & 279 & Penduletin & [28] \\
\hline 38. & 377.1957 & 7.56 & $\mathrm{C}_{21} \mathrm{H}_{29} \mathrm{O}_{6}$ & -1.9 & $\begin{array}{l}377.1957,345.1701 \\
301.1799,189.1278\end{array}$ & 350 & Hypophyllin E & First report * \\
\hline 39. & 285.0764 & 7.62 & $\mathrm{C}_{16} \mathrm{H}_{12} \mathrm{O}_{5}$ & 1.5 & $\begin{array}{l}285.0403,286.0438 \\
533.2025,571.0843\end{array}$ & 261 & Sakuranetin & [27] \\
\hline 40. & 255.0662 & 7.78 & $\mathrm{C}_{15} \mathrm{H}_{11} \mathrm{O}_{4}$ & 1.2 & $\begin{array}{l}255.0660,151.0035 \\
213.0554,107.0135\end{array}$ & 288 & Pinocembrin & [17] \\
\hline 41. & 347.1857 & 7.91 & $\mathrm{C}_{20} \mathrm{H}_{27} \mathrm{O}_{5}$ & -0.3 & $\begin{array}{l}347.1850,303.1965 \\
285.1488,241.1591\end{array}$ & weak & $\begin{array}{c}\text { (A)-6a-Hydroxy-5a,8a,9a,10a-cleroda-3, } \\
\text { 13-dien-16,15-olid-18-oicacid }\end{array}$ & [10] \\
\hline 42. & 299.0560 & 7.96 & $\mathrm{C}_{16} \mathrm{H}_{11} \mathrm{O}_{6}$ & 1.3 & $\begin{array}{l}299.055,271.0605 \\
65.0193,284.0329\end{array}$ & 266,365 & Rhamnocitrin & [17] \\
\hline 43. & 313.0713 & 8.20 & $\mathrm{C}_{17} \mathrm{H}_{13} \mathrm{O}_{6}$ & 0.7 & $\begin{array}{l}313.0712,314.0749 \\
377.1953,298.0486\end{array}$ & 361 & Kumatakenin & [17] \\
\hline 44. & 343.0812 & 8.41 & $\mathrm{C}_{18} \mathrm{H}_{15} \mathrm{O}_{7}$ & -1.7 & $\begin{array}{l}343.0812,313.0346 \\
301.1798,270.0161\end{array}$ & 270,340 & Santin & [17] \\
\hline 45. & 413.1236 & 8.76 & $\mathrm{C}_{22} \mathrm{H}_{21} \mathrm{O}_{8}$ & 0.5 & $\begin{array}{l}413.1231,368.0905 \\
331.1908,161.0144\end{array}$ & 351 & Picropodophyllin & First report * \\
\hline
\end{tabular}


Table 2. Cont

\begin{tabular}{|c|c|c|c|c|c|c|c|c|}
\hline & $\begin{array}{l}\text { Experimental } \mathbf{m} / \mathbf{z} \\
\quad[\mathbf{M}-\mathbf{H}]^{-}\end{array}$ & $\begin{array}{l}\text { Retention Time } \\
\text { (min) }\end{array}$ & Formula & PPM Error & MSE Fragments & UV (nm) & Proposed Compound & References \\
\hline 46. & 367.1180 & 8.91 & $\mathrm{C}_{21} \mathrm{H}_{19} \mathrm{O}_{6}$ & -0.5 & $\begin{array}{c}352.0954,323.0915 \\
297.0328,269.044\end{array}$ & 267 & 7-O-methylluteone & First report * \\
\hline 47. & 313.0720 & 8.98 & $\mathrm{C}_{17} \mathrm{H}_{13} \mathrm{O}_{6}$ & 2.6 & $\begin{array}{l}313.0720,283.0252, \\
255.0296,161.0255\end{array}$ & 267,347 & 3,5-Dihydroxy-4',7-dimethoxyfla-vone & {$[17,27]$} \\
\hline 48. & 331.1910 & 9.19 & $\mathrm{C}_{20} \mathrm{H}_{27} \mathrm{O}_{4}$ & 0.3 & $\begin{array}{l}\text { 331.1914, 397.1290, } \\
332.1949,398.1334\end{array}$ & 340 & Hautriwaic acid & [17] \\
\hline 49. & 397.1280 & 9.31 & $\mathrm{C}_{22} \mathrm{H}_{21} \mathrm{O}_{7}$ & -0.4 & $\begin{array}{l}\text { 397.1291, 1169.585, } \\
331.1901,1156.5643\end{array}$ & weak & $\begin{array}{l}\text { 5,7,3'-Trihydroxy-3,5'-dimethoxy-2'- } \\
\left(3^{\prime} \text {-methylbut-2-enyl)flavone }\right.\end{array}$ & [26] \\
\hline 50. & 483.2021 & 9.35 & $\mathrm{C}_{27} \mathrm{H}_{31} \mathrm{O}_{8}$ & 0.2 & $\begin{array}{c}483.2018 \\
453.1683,331.1906 \\
397.1288\end{array}$ & 341 & $\begin{array}{l}\text { 5,7,4'-Trihydroxy-3'-(4-hydroxy- } \\
\text { 3-Methylbutyl)-5'-prenyl-3, } \\
\text { 6-diMethoxyflavone }\end{array}$ & [26] \\
\hline 51. & 293.2117 & 9.58 & $\mathrm{C}_{18} \mathrm{H}_{29} \mathrm{O}_{3}$ & -1.4 & $\begin{array}{l}\text { 293.2111,161.0242, } \\
152.9944,265.1489 \\
\end{array}$ & 267,347 & 17-Hydroxylinolenic acid & First report * \\
\hline 52. & 321.2443 & 10.08 & $\mathrm{C}_{20} \mathrm{H}_{33} \mathrm{O}_{3}$ & -2.43 & $277.2537,116.938$ & weak & diterpenoid & First report * \\
\hline 53. & 411.1444 & 10.19 & $\mathrm{C}_{23} \mathrm{H}_{23} \mathrm{O}_{7}$ & 0 & $\begin{array}{l}411.1439,396.1214 \\
331.1898,265.1464\end{array}$ & 340 & Viscosol & [28] \\
\hline 54. & 435.1808 & 10.36 & $\mathrm{C}_{26} \mathrm{H}_{27} \mathrm{O}_{6}$ & -1.6 & $\begin{array}{l}435.1806,255.2322 \\
365.102,161.0247\end{array}$ & weak & Artocarpin & First report * \\
\hline 55. & 277.2168 & 11.33 & $\mathrm{C}_{18} \mathrm{H}_{29} \mathrm{O}_{2}$ & 0 & $\begin{array}{l}277.2163,116.9271 \\
265.1465,152.9955\end{array}$ & weak & Punicic acid & First report * \\
\hline
\end{tabular}

* First report means they have not been previously reported in D. viscosa. Literature references for compounds previously reported in $D$. viscosa are also indicated. 


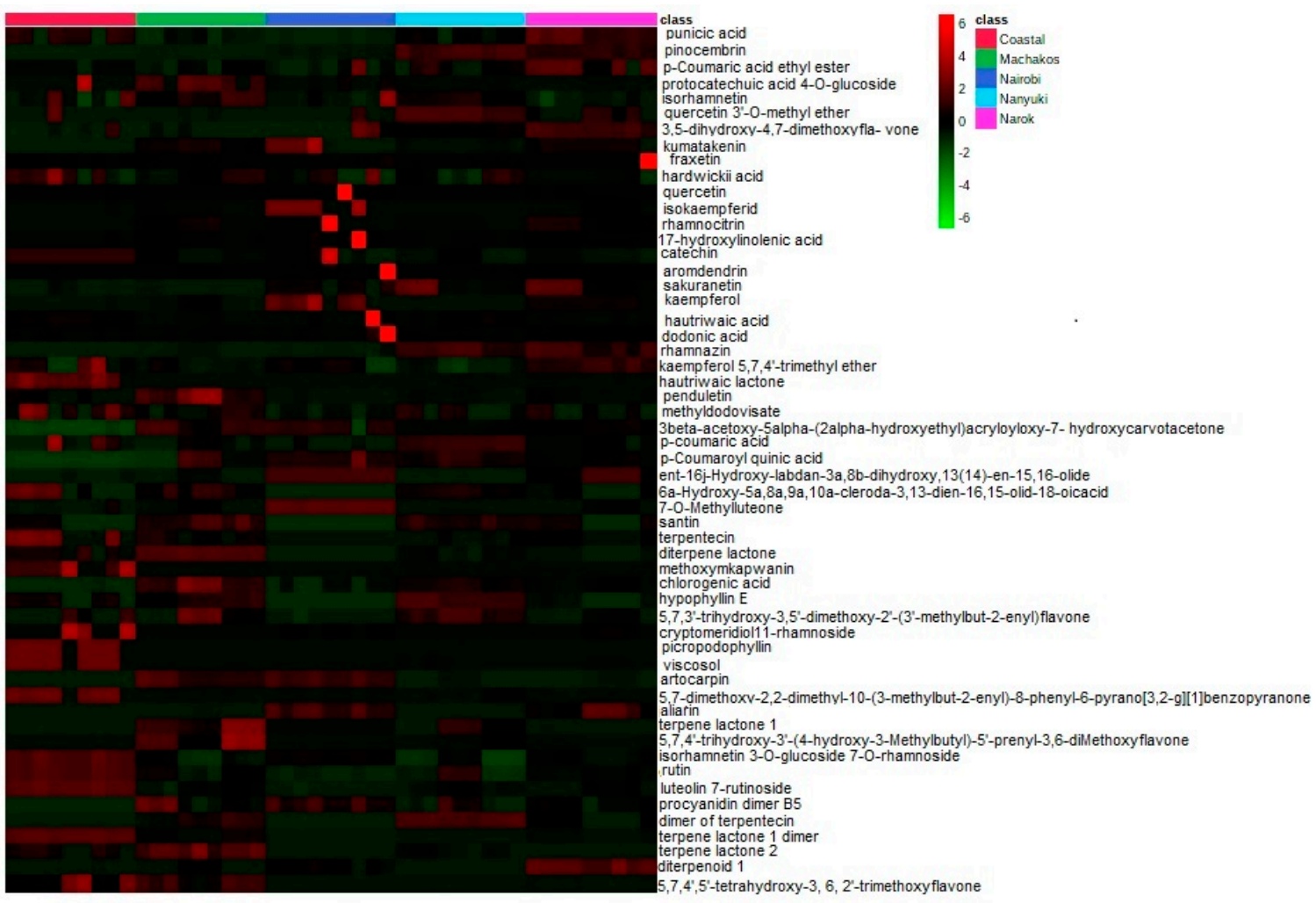

Figure 2. Heat map showing the relative abundance of the identified compounds in each population.

\subsection{Chemotype Variation}

Principal component (PC) 1 and 2 accounted for $28 \%$ and $17.2 \%$, respectively, of the variance (Figure 3A). Principal component 1 usually accounts for the major variation on the $x$-axis while PC 2 accounts for minor variation in the y-axis. According to the two PC scores, the Nanyuki and Machakos clusters fell in the same quadrat and appeared to cluster closer to each other in addition to production of similar metabolites in almost equal relative amounts leading to our choice of using an orthogonal partial least square-discriminant analysis (OPLS-DA) test to further separate them. The OPLS-DA test is suitable for diagnosing the differences between two groups or systems which are closely related, as it has the potential to reduce the dimensionality of metabolomics datasets [30]. Eleven metabolites were identified as the discriminants of the five populations of $D$. viscosa (Table 3 and Figure $3 \mathrm{~B}$ ). The majority of these chemicals belong to the flavonoid class of compounds and dodonic acid, ent-16j-hydroxy-labdan-3a, 8b-dihydroxy, 13(14)-en-15, 16-olide, hypophylin E, and terpenticin are from the diterpenoid group.

From the score plot of the OPLS-DA test (Figure 4A) it was apparent that the Machakos and Nanyuki collections were distinct from each other based on chemical composition. The members within the Machakos population differentiated into two distinct sub-clusters, suggesting inherent chemical bias within this population of plants (Figure 4A), similar to the Narok population in Figure 3A. This sub-clustering could be due to intraspecific hybridization, with members from populations occurring in adjacent ecological zones. Intraspecific hybridization is important for developing environmentally adaptive traits [31]. The OPLS-DA analysis (Figure 4B) revealed that sets of unique chemicals which were absent in the Nanyuki group were present in the collections from the Machackos area and vice versa. The chemical discriminants identified in the Nanyuki population were santin, pinocembrin, and dodonic acid, whereas those from the Machakos region were kumatakenin, penduletin, and 5,7,4'-trihydroxy-3'-(4-hydroxy-3-methylbutyl)-5'-prenyl-3,6-dimethoxyflavone. Therefore, the OPLS-DA was powerful in diagnosing the differences between two systems or groups by determining the variables with high discriminatory power [32]. 

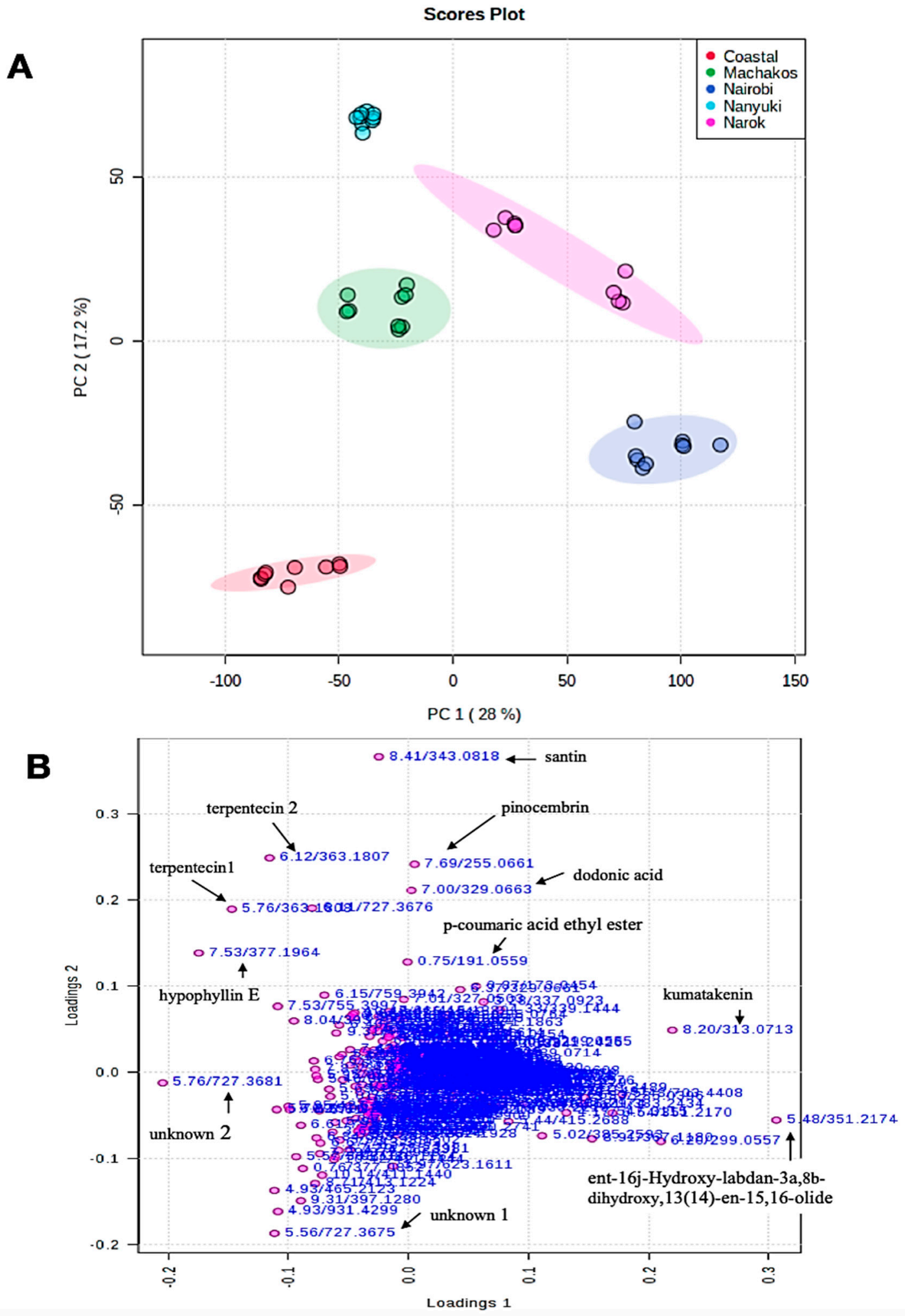

Figure 3. (A) Principal component analysis (PCA) score plot showing variation of D. viscosa plants from different natural population five different locations in Kenya, i.e., coastal region (red color), Machakos (green color), Nairobi (blue color), Nanyuki (cyan color), and Narok (purple color); (B) PCA loadings plot of compounds that influenced the differentiation of collections into separate clusters. 

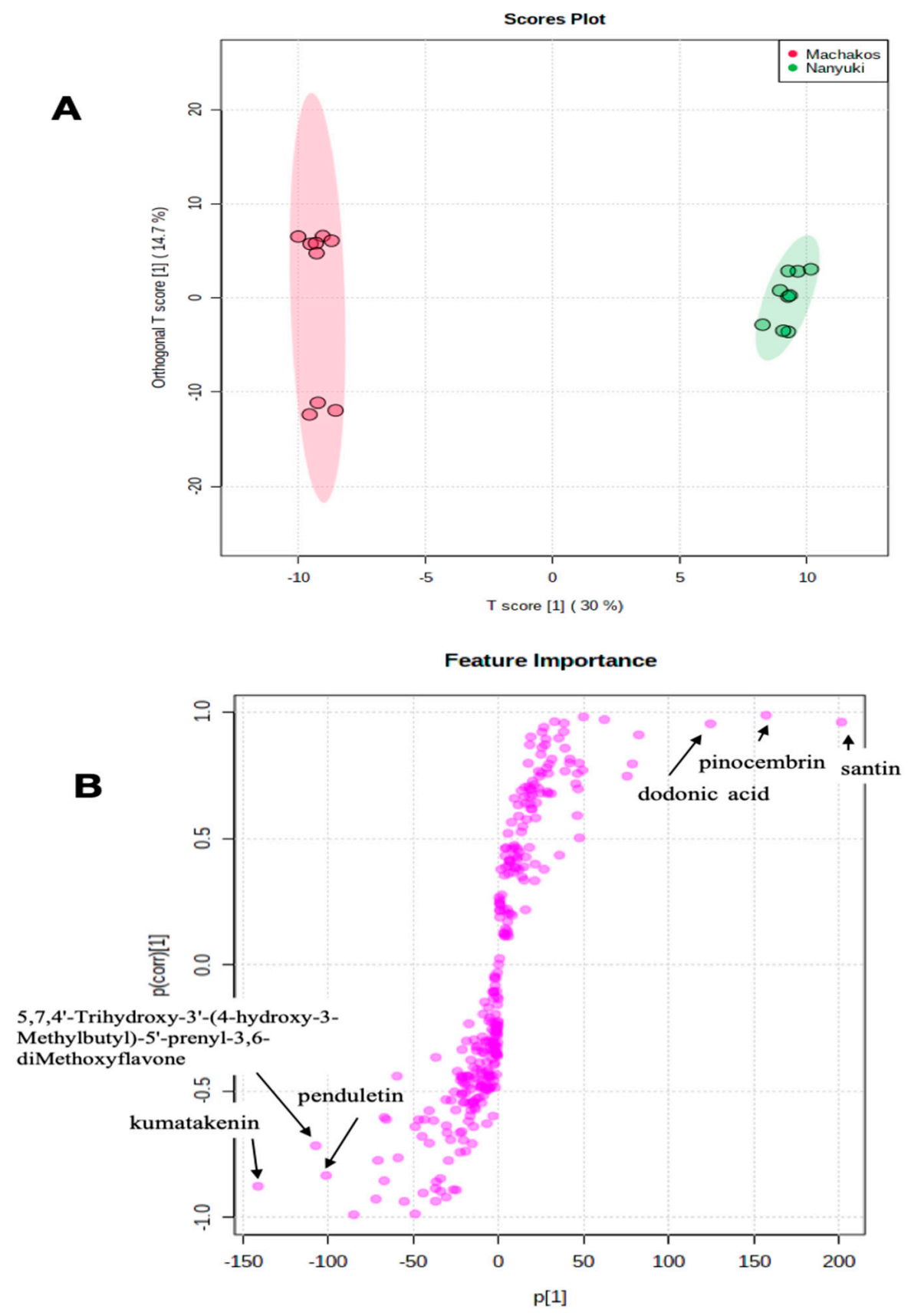

Figure 4. (A) Orthogonal partial least squares discriminant analysis (OPLS-DA) for Dodonaea viscosa Nanyuki and Machakos populations. The OPLS-DA test separation of Machakos and Nanyuki populations of $D$. viscosa was based on T score 1 which was 30\% separating Machakos population on the left and the Nanyuki population on the right; (B) Loadings of OPLS-DA of LC-MS spectra for D. viscosa Nanyuki and Machakos populations showing the compounds that are important discriminants.

Absolute quantification of discriminants identified from the five different collections of $D$. viscosa plants (Table 3) showed that the Nanyuki population had the highest relative abundance of six chemical markers (santin, pinocembrin, dodonic acid, p-coumaric acid ethyl ester, terpenticin 2, and hypophyllin E) (Figure 5). The Gazi coastal and Nairobi plants each had higher levels of three and two chemicals, respectively, that discriminated the collections based on site. For the coastal types, two dimers of terpentecin and terpenticin 1 were differentially accumulating. As opposed to this, the Nairobi group had kumatakenin and ent-16j-hydroxy-labdan-3a,8b-dihydroxy,13(14)-en-15,16-olide as the chemicals that were upregulated. 
Table 3. List of discriminants identified in D. viscosa populations in this study showing retention time, detected $[\mathrm{M}-\mathrm{H}]^{-}$ion, elemental composition, as well as the population with highest relative abundance of each discriminant.

\begin{tabular}{cccccc}
\hline & $\begin{array}{c}\text { Retention } \\
\text { Time (min) }\end{array}$ & $\begin{array}{c}\text { ESI negative } \\
{[\mathbf{M}-\mathbf{H}]^{-(m / z)}}\end{array}$ & $\begin{array}{c}\text { Elemental } \\
\text { Composition }\end{array}$ & Name & $\begin{array}{c}\text { Population with } \\
\text { Highest Concentration }\end{array}$ \\
\hline 1. & 0.75 & 191.0559 & $\mathrm{C}_{10} \mathrm{H}_{7} \mathrm{O}_{4}$ & p-coumaric acid ethyl ester & Nanyuki \\
\hline 2. & 5.48 & 351.2174 & $\mathrm{C}_{20} \mathrm{H}_{31} \mathrm{O}_{5}$ & $\begin{array}{c}\text { ent-16j-hydroxy-labdan-3a,8b-dihydroxy, } \\
\text { 13(14)-en-15,16-olide }\end{array}$ & Nairobi \\
\hline 3. & 5.76 & 363.1808 & $\mathrm{C}_{20} \mathrm{H}_{27} \mathrm{O}_{6}$ & terpentecin 1 & coastal (Gazi) \\
\hline 4. & 5.76 & 727.3681 & $\mathrm{C}_{40} \mathrm{H}_{55} \mathrm{O}_{12}$ & dimer of terpentecin 1 & coastal (Gazi) \\
\hline 5. & 6.11 & 727.3676 & $\mathrm{C}_{40} \mathrm{H}_{55} \mathrm{O}_{12}$ & dimer of terpentecin 2 & coastal (Gazi) \\
\hline 6. & 6.12 & 363.1807 & $\mathrm{C}_{20} \mathrm{H}_{27} \mathrm{O}_{6}$ & terpentecin 2 & Nanyuki \\
\hline 7. & 7.00 & 329.0663 & $\mathrm{C}_{20} \mathrm{H}_{25} \mathrm{O}_{4}$ & dodonic acid & Nanyuki \\
\hline 8. & 7.53 & 377.1964 & $\mathrm{C}_{21} \mathrm{H}_{29} \mathrm{O}_{6}$ & hypophyllin $\mathrm{E}$ & Nanyuki \\
\hline 9. & 7.69 & 255.0661 & $\mathrm{C}_{15} \mathrm{H}_{11} \mathrm{O}_{4}$ & pinocembrin & Nanyuki \\
\hline 10. & 8.20 & 313.07 & $\mathrm{C}_{17} \mathrm{H}_{13} \mathrm{O}_{6}$ & kumatakenin & Nairobi \\
\hline 11. & 8.41 & 343.0818 & $\mathrm{C}_{18} \mathrm{H}_{15} \mathrm{O}_{7}$ & santin & Nanyuki \\
\hline
\end{tabular}

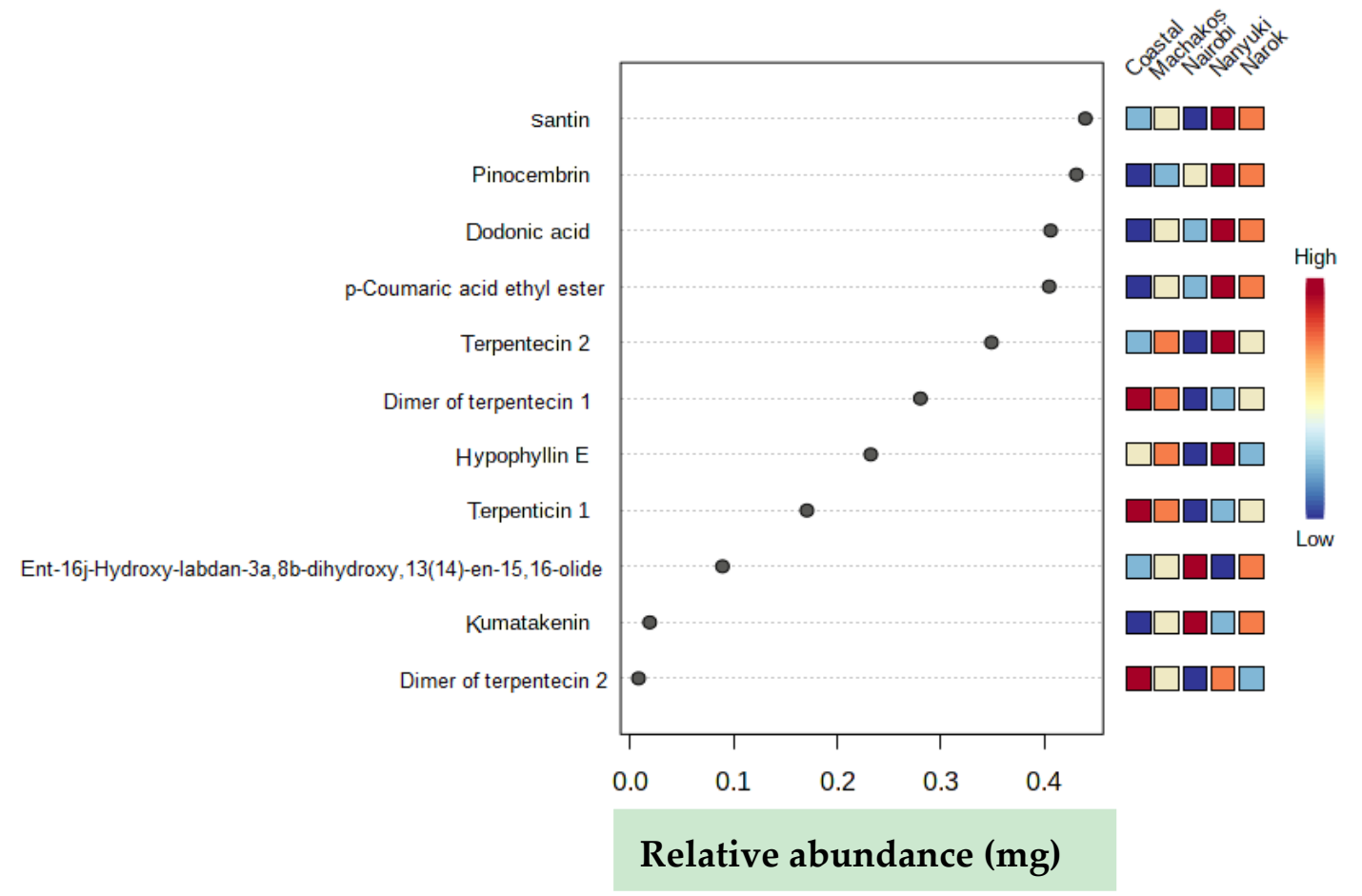

Figure 5. Relative abundance of chemical discriminants in different $D$. viscosa populations. The dark red color shows high relative abundance of the individual chemical in each population while the dark blue color implies a low relative abundance.

Extensive natural disparity in phytochemical profiles occurs between and within species of plants as an adaptation measure to different abiotic and biotic environments [32]. The most important players in the biosynthesis and accumulation of secondary metabolites include genetics, epigenetics, morphogenetic, ontogenic, and environmental factors [33]. The PCA, as shown in Figure 3A, indicates that Nanyuki and Machakos populations of $D$. viscosa are closely related while the plants from the Nairobi and Narok areas are from a similar chemical lineage. The current morphological classification of the genus Dodonaea in Kenya shows that the coastal population is believed to be composed of $D$. viscosa subsp viscosa, whereas plants from the other locations are composed of $D$. viscosa subsp angustifolia [14]. The data of this study do not offer support for this idea. Instead, our data 
suggest that chemicals produced by the plants from different areas are related to the geographical and environmental conditions prevailing at the sites where each population was collected [34].

The production of specialized metabolites in plants is meant to help plants fight natural enemies, as well as counteract with other forms of natural biotic and abiotic stress including those created through anthropogenic activities such as pollution [35]. The environmental conditions prevailing in the Machakos and Nanyuki areas include drought together with high daytime temperatures and very low temperatures at night [36]. Hypothetically, it is possible that such differences in geoclimatic conditions can lead to variable chemistry that enables the plant to adapt to stress. Certainly, the Nairobi and Narok populations are faced with natural enemies such as browsers (Narok), as well as environmental stress such as pollution (Nairobi population) [35]; and thus, the group of chemicals produced by these populations is possibly meant to counter pollution and browsing effects experienced by these populations.

Both biotic and abiotic factors such as drought, browsing, salinity, heat, and air pollutants lead to heightened production of reactive oxygen species (ROS) in plants [37]. Studies have demonstrated the importance of non-enzymatic systems of intracellular antioxidant defense machinery in countering a variety of stresses. These non-enzymatic systems are mediated by antioxidants such as flavonoids [38]. Plants from the Gazi coast were found to have a different group of discriminants. Although this is speculative, it can be argued that these chemicals facilitate environmental adaptations specially to counter high temperatures and salinity $[38,39]$. The temperatures in the Gazi region can vary from 24 to $30{ }^{\circ} \mathrm{C}$ and because of a coastal locality, the soils are likely to be more saline. Flavonoids and diterpenoids such as catechin and hautriwaic acid lactone are implicated in stress responses in plants, and thus it is not surprising that these compounds were much higher in the plants from this hot and humid coastal region. This could possibly explain why samples from this area have close chemical similarities to the Nanyuki and Machakos cluster as compared with the plants growing in the Nairobi and Narok locations.

It can be argued that the metabolite production by the different populations of $D$. viscosa in Kenya is possibly based on prevailing environmental conditions [40]. This is probably influenced by epigenetic mechanisms which enhance phenotypic plasticity possibly as an adaptation to address the different levels of environmental stresses and in such cases, this can be transmitted successfully to the next offspring for numerous generations ultimately leading to transgenerational changes that evolve over time [32]. We propose this idea as the plants that are currently classified as D. viscosa subsp viscosa, growing in the Gazi coast, are in fact more similar in their phytochemical composition to the Nanyuki and Machakos populations that are composed of plants that have been designated to be D. viscosa subsp. angustifolia. On the contrary, the Narok and Nairobi populations, which are composed of D. viscosa subsp angustifolia, were found to have no relatedness with Nanyuki and Machakos populations, which were also composed of $D$. viscosa subsp angustifolia. This is the first report on the relatedness of D. viscosa populations in Kenya, and based on the data presented in this study, a revision of the taxonomic classification is needed. Other molecular based techniques, such as a phylogenetic analysis could provide new insights into the taxonomy of D. viscosa in Kenya.

\subsection{Secondary Metabolites Isolated from Gazi Coastal Population of Dodonaea viscosa}

The coastal population of D. viscosa $\mathrm{CH}_{2} \mathrm{Cl}_{2} / \mathrm{CH}_{3} \mathrm{OH}$ (1:1) extract yielded four known compounds (Figure S1) which were identified by MS and NMR (using COSY, HSQC, NOESY, and HMBC) analyses (see Supplementary Material) as dodonic acid (1) $\mathrm{C}_{20} \mathrm{H}_{28} \mathrm{O}_{4}$ [17], 5,7,4', 5' -tetrahydroxy3,6,2' -trimethoxyflavone (2) $\mathrm{C}_{18} \mathrm{H}_{16} \mathrm{O}_{9}$ ) [41]; hautriwaic acid lactone (3) $\mathrm{C}_{20} \mathrm{H}_{26} \mathrm{O}_{3}$ ) [17]; and catechin (4) $\mathrm{C}_{15} \mathrm{H}_{14} \mathrm{O}_{6}$ [42]. This is the first report on the isolation of 5,7,4', $5^{\prime}$-tetrahydroxy-3,6,2'-trimethoxyflavone (2) from D. viscosa.

The relative abundance of dodonic acid (1) was high in all the five populations, whereas hautriwaic acid lactone (3) was present in Nanyuki, Machakos and Gazi coastal collections (Figure 6). In addition, 
the relative abundance of 5,7,4',5'-tetrahydroxy-3,6,2'-trimethoxyflavone (2) was high in the Gazi coastal plants as compared with the other groups.

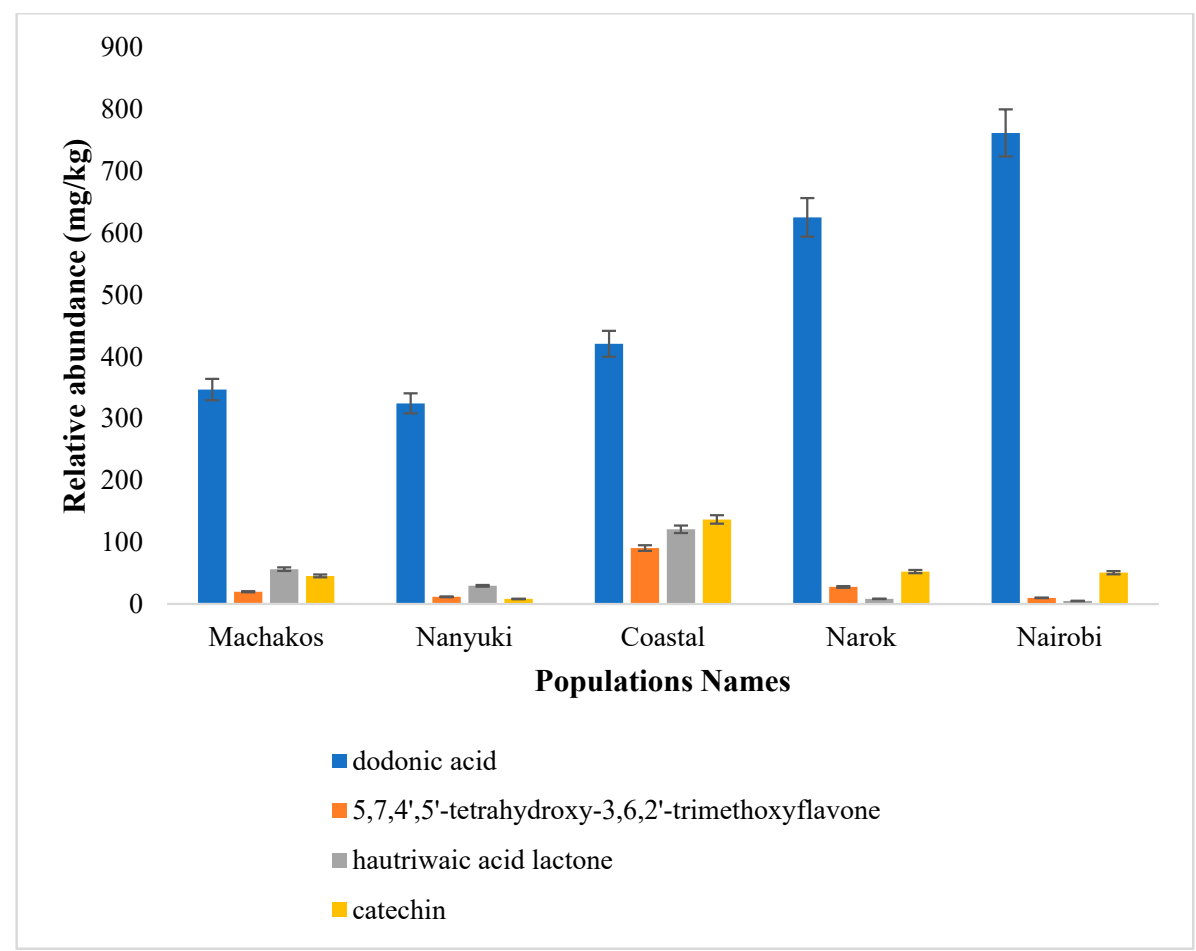

Figure 6. Concentrations (mg/kg) of the isolated compounds (dodonic acid (1), 5,7,4', $5^{\prime}$-tetrahydroxy3,6,2'-trimethoxyflavone (2), hautriwaic acid lactone (3), and catechin (4) in the five Kenyan D. viscosa populations.

\subsection{Antimicrobial Activity of the Isolated Compounds and the Extracts}

Many plant secondary metabolites are known to possess a wide range of biological activities such as antifungal, antioxidant, antibacterial, antidiabetic, and anticancer activities $[43,44]$. D. viscosa has been reported to possess antimicrobial activity against microbes of economic importance [45-48]. Diterpenoids are known to possess antimicrobial and antioxidant potencies [49,50]. This prompted us to test the antimicrobial activity of the four isolated compounds from this plant against both Gram-positive (MRSA and S. aureus), Gram-negative (E. coli), and fungi (C. albicans) (Table 4). On the one hand, of the two diterpenoids isolated, dodonic acid (1) exhibited low activity against $S$. aureus and E. coli and was inactive against MRSA and C. albicans. On the other hand, hautriwaic acid lactone (3) with a similar structure to dodonic acid (1), except for the presence of a lactone ring, showed good activity against all the tested microbes. The MIC values for both S. aureus and E. coli were $1.95 \mu \mathrm{g} / \mathrm{mL}$, MRSA $62.5 \mu \mathrm{g} / \mathrm{mL}$, and $7.81 \mu \mathrm{g} / \mathrm{mL}$ for $C$. albicans. These results indicate the importance of a lactone moiety in the inhibition of microbial growth [51]. The report of antimicrobial activity of hautriwaic acid lactone is in agreement with the work of Omosa et al. [17] who found that this compound had good antifungal activity against $S$. cerevisiae with a MIC value of $7.8 \mu \mathrm{g} / \mathrm{well}$, probably due to its lipophilic nature.

Plant flavonoids have been reported to exhibit a wide range of biological activities including antibacterial, antioxidant, anticancer, and antifungal [52,53]. Interestingly, catechin (4), a flavonoid purified from D. viscosa, inhibited the growth of the four tested microbes with MIC values for S. aureus and E. coli of $3.91 \mu \mathrm{g} / \mathrm{mL}$, and $7.81 \mu \mathrm{g} / \mathrm{mL}$ for MRSA and C. albicans. The antimicrobial activity of catechin is inconsistent with those reported in other studies [54-57]. 5,7,4', $5^{\prime}$-tetrahydroxy3,6,2'-trimethoxyflavone (2), a flavonoid with similar oxygenation pattern with catechin except for the absence of $\mathrm{OH}$ groups at carbon 3 and $3^{\prime}$ did not inhibit the growth of any of the microbes 
tested, confirming the importance of hydroxyl groups in those carbons for antimicrobial activity in flavonoids. Hydroxyls at special sites on the aromatic rings of flavonoids are known to improve their biological activities, whereas methylation of the active $\mathrm{OH}$ groups generally decreases such activities [58]. The coastal Gazi population extracts were the most active followed by the extracts from the Nanyuki plants, whereas the Narok plant collections had the least active extracts. The activity of the coastal plants against S. aureus and E. coli was similar to catechin (4) while the Nanyuki extract and hautriwaic acid lactone (3) were similar to each other in the inhibition of the growth of C. albicans.

Table 4. MIC values $(\mu \mathrm{g} / \mathrm{mL})$ for the four isolated compounds from the coastal population of $D$. viscosa and the extracts from the five populations against methicillin resistant Staphylococcus aureus (MRSA), Staphylococcus aureus, Escherichia coli, and Candida albicans.

\begin{tabular}{ccccc}
\hline Sample Name & \multicolumn{4}{c}{ Microbial Names } \\
\cline { 2 - 5 } & MRSA & S. aureus & E. coli & C. albicans \\
\hline Dodonic acid (1) & $>1000$ & 500 & 500 & $>1000$ \\
$5,7,4^{\prime}, 5^{\prime}$-Tetrahydroxy-3,6,2' trimethoxyflavone (2) & $>1000$ & $>1000$ & $>1000$ & $>1000$ \\
Hautriwaic acid lactone (3) & 62.50 & 1.95 & 1.95 & 7.81 \\
Catechin (4) & 7.81 & 3.91 & 7.81 & 3.91 \\
Coastal (Gazi) & 62.50 & 3.91 & 7.81 & 15.62 \\
Machakos & 125 & 7.81 & 15.62 & 31.20 \\
Nairobi & $>1000$ & 31.25 & 62.50 & $>1000$ \\
Nanyuki & 62.50 & 7.81 & 15.62 & 7.81 \\
Narok & 125 & 15.62 & 31.25 & 62.5 \\
\hline Omacilin & 0.98 & 0.49 & 0.98 & - \\
Fluconazole & & & & 1.95 \\
\hline
\end{tabular}

\section{Materials and Methods}

\subsection{Collection of Plant Materials}

D. viscosa plants samples were collected from different natural origins across five localities in Kenya. Four collection sites, i.e., Nanyuki, Machakos, Karura, and Narok were from Kenyan inland regions and were composed of D. viscosa var angustifolia. The Gazi collection site is along the Kenyan coast and the plants collected there were composed of D. viscosa var. viscosa. Three samples from different individual plants were taken from each population. Sampling of specimens was conducted in April 2018. Voucher specimens were deposited at the Nairobi University Herbarium after the confirmation of the taxonomic identities by Dr C. Lukhoba (a botanist at the University of Nairobi, Nairobi, Kenya). Details of voucher specimens and geographic collection localities are as shown in Table 1. The plants' materials were washed, cut into smaller leaf pieces (size $2 \mathrm{~cm}$ ), and dried away from direct sunlight, at room temperature for 15 days. This was followed by grinding each sample separately by hand, in a pestle and mortar.

\subsection{Extraction for Metabolite Profiling}

A similar protocol to that of Albrecht et al. [23] was used in this study. Briefly, $50 \mathrm{mg}$ from each sample was extracted with 50\% (v/v) acetonitrile (Romil far UV grade, Microsep, Johannesburg, South Africa) containing 0.1\% (v/v) formic acid (Sigma-Aldrich, Johannesburg, South Africa). In all cases, ultrapure water (MilliQ) was used as a diluent. This study was carried out at the Central Analytical Facilities (CAF), Stellenbosch University, Stellenbosch, South Africa.

\section{Standards}

Two standards were obtained from Sigma-Aldrich (Johannesburg, South Africa), i.e., quercetin and catechin, and were analytically weighed and dissolved in dimethyl sulfoxide (DMSO) and diluted in methanol to set up a calibration series of 10, 20, 50, 100, and 200 ppm. 


\subsection{Liquid Chromatography Mass Spectrometry (LC-MS) Analysis}

Analysis was performed using a Waters Synapt G2 quadrupole time-of-flight High Definition Mass Spectrometer (Milford, MA, USA), linked to a Waters Acquity ultra-performance liquid chromatograph (UPLC) and Acquity photo diode array (PDA) detector. Ionization was achieved with an electrospray source using a cone voltage of $15 \mathrm{~V}$ and capillary voltage of $2.5 \mathrm{kV}$ in negative mode. Nitrogen was used as the desolvation gas at $6501 \mathrm{~h}^{-1}$ and the desolvation temperature was set to $275^{\circ} \mathrm{C}$. A Waters UPLC BEH C18 column $(2.1 \times 100 \mathrm{~mm}, 1.7 \mu \mathrm{m}$ particle size $)$ was used and $3 \mu \mathrm{L}$ was injected for each analysis. The gradient started with $100 \%$ using $0.1 \%(v / v)$ formic acid (solvent $\mathrm{A}$ ) and this was kept at $100 \%$ for $0.5 \mathrm{~min}$, followed by a linear gradient to $22 \%$ acetonitrile (solvent B) over $2.5 \mathrm{~min}, 44 \%$ solvent B over $4 \mathrm{~min}$, and finally to $100 \%$ solvent B over $5 \mathrm{~min}$. The column was subjected to $100 \%$ solvent $\mathrm{B}$ for an additional $2 \mathrm{~min}$. Then, the column was re-equilibrated over $1 \mathrm{~min}$ to yield a total run time of $15 \mathrm{~min}$. A flow rate of $0.4 \mathrm{~mL} \mathrm{~min}^{-1}$ was applied. The MSE mode was used to acquire the data with a low collision energy scan followed by a high collision energy scan with collision energy ramped from 20 to 60 to obtain both molecular ion $[\mathrm{M}-\mathrm{H}]^{-}$and fragment data at the same time. For each biological replicate of the materials collected, there were three technical replicates analyzed.

\subsection{Extraction and Isolation of Compounds: Gazi Coastal Population}

Ground material of $(800 \mathrm{~g})$ of Dodonaea viscosa Gazi coastal plants was exhaustively and sequentially extracted with a sufficient amount of methanol $\left(\mathrm{CH}_{3} \mathrm{OH}\right) /$ dichloromethane $\left(\mathrm{CH}_{2} \mathrm{Cl}_{2}\right)$ in the ratio of 1:1, for $72 \mathrm{~h}$. The resultant extract was filtered to remove debris and the solvent was removed in vacuo using a rotary evaporator and resulted in $220 \mathrm{~g}$ of the crude extract. A portion of this extract $(50 \mathrm{~g})$ was adsorbed in $100 \mathrm{~g}$ of silica gel 60 (70-230 mesh) and subjected to column chromatography on silica gel 60 (70-230 mesh) (700 g) packed under 100\% $n$-hexane. The column was eluted with $100 \% n$-hexane followed by increasing polarity of EtOAc in $n$-hexane starting from $1 \%$ to $100 \%$ of EtOAc, followed by $\mathrm{CH}_{3} \mathrm{OH}$ in EtOAc in increasing percentages. A total of 240 fractions, each $400 \mathrm{~mL}$, were collected and combined on the basis of TLC (on silica gel 60 F254, Merck) analysis. Elutions made at 1-15\% of EtOAc in $n$-hexane did not yield any compound but resulted in oily substances. Fractions eluted between $15 \%$ and $30 \%$ of EtOAc in $n$-hexane were combined and washed with $n$-hexane/EtOAc (3:2) to give a white amorphous solid 1 (100 mg). Elutions obtained at $40 \%$ of EtOAc in $n$-hexane were combined and washed with $n$-hexane/EtOAc (3:2) to yield a yellow powder of 2 (11 mg). Fractions obtained between $40 \%$ and $100 \%$ were further combined to yield $10 \mathrm{~g}$, and further separated by column chromatography over silica gel using $n$-hexane containing increasing polarity of EtOAc and yielded a white amorphous compound $2(29 \mathrm{mg})$ at $30 \%$ of EtOAc in $n$-hexane elution.

\subsection{Characterization of Pure Compounds}

This was carried out at the University of Potsdam (Brandenburg, Germany) and the Central Analytical Facility, Stellenbosch University (Stellenbosch, South Africa). Structures of the purified compounds were determined through ${ }^{1} \mathrm{H}-,{ }^{13} \mathrm{C}-\mathrm{NMR}$ using Bruker Avance $500 \mathrm{MHz}$ spectrometers, and HMBC, HSQC, COSY, and NOESY spectroscopy using standard Bruker software. Chemical shifts were measured in $\mathrm{ppm}$ in $\delta$ values relative to the internal standard tetramethyl silane (TMS).

\subsection{Antimicrobial Activity of the Isolated Compounds}

All the pure compounds and extracts from the five populations were tested for antimicrobial activity against the following: Staphylococcus aureus (ATCC 29213), Escherichia coli (ATCC 25922), Candida albicans (ATCC 10231), and un-typed isolate of methicillin resistant Staphylococcus aureus (MRSA). The microbes were obtained from the Centre for Microbiology Research (CMR), Kenya Medical Research Institute (KEMRI). The stock solutions of the compounds were prepared by separately dissolving $1 \mathrm{mg}$ of each compound in $1 \mathrm{~mL}$ of $10 \%$ DMSO to make $1000 \mu \mathrm{g} / \mathrm{mL}$. The minimal inhibition concentration (MIC) of the chemical isolates from the Gazi coast population of D. viscosa was determined using a broth dilution 
technique. All the compounds and extracts were diluted serially, ranging from 1000 to $0.011 \mu \mathrm{g} / \mathrm{mL}$ in 96 micro well plates. For each dilution, $1 \mathrm{~mL}$ of 24-hour and 72-hour cultured bacteria and fungi, respectively, were added, adjusted to McFarland turbidity [59,60], and placed in an incubator at $37^{\circ} \mathrm{C}$ for $24 \mathrm{~h}$ for bacteria, and $30^{\circ} \mathrm{C}$ for $72 \mathrm{~h}$ for fungi. The experiment was carried out in triplicate. The lowest dilution for each compound with invisible microbial growth was recorded as MIC. This was confirmed by absence of turbidity after inoculating into agar followed by incubation for 24 and $72 \mathrm{~h}$ for bacteria and fungi, respectively [61]. Omacilin and fluconazole obtained from Sigma-Aldrich (St. Louis, Missouri, USA) served as positive controls for bacteria and fungi, respectively, whereas 10\% DMSO was used as a negative control.

\subsection{Statistical Analysis}

Three biological replicates and three technical replicates were injected randomly to the LC-MS machine for each test sample. Untargeted analysis of the data was performed using MarkerLynx (part of MassLynx 4.1, Waters, Milford, USA) to generate a matrix of accurate mass and retention time (AMRT) features uploaded to MetaboAnalyst, a free online software platform, to perform the chemometric analysis. Targetlynx, another application within Masslynx, was used to quantify the various tentatively identified metabolites in a relative fashion, against calibration curves established using either catechin or quercetin calibration standards. The principal component analysis (PCA) model with pareto scaling was used as an unsupervised multivariate cluster technique. Pareto scaling increases the contributory effects of low concentration metabolites but does not amplify noise and artefacts linked to metabolomics data [62]. Therefore, this simplifies the interpretation of loading score plots [63]. Interrelationships were revealed through PCA based on three components (MS data, relative abundances, and spatial distribution) for the test materials. The instrument variation was negligible and replicates clustered close to each other. Where members from different sites appeared to cluster together, orthogonal partial least squares discriminant analysis (OPLS-DA) was performed to further separate them. The accurate mass obtained for the molecular ions $[\mathrm{M}-\mathrm{H}]^{-}$was used to calculate the possible molecular formula, considering a maximum deviation between observed and calculated mass of $5 \mathrm{ppm}$. The molecular formula, accurate mass, and MSE fragmentation spectra, were used as entry data for MetFrag $\beta$-database analysis [64] to identify the compounds where possible.

\section{Conclusions}

This study does not support the current morphological classification of the genus D. viscosa in Kenya, where the coastal population is said to be composed of $D$. viscosa subsp viscosa, whereas the in-country are classified as D. viscosa subsp angustifolia. The metabolomics data indicate the Gazi coast (D. viscosa subsp viscosa) population to be chemically similar to the Nanyuki and Machakos populations that are composed of plants that have been designated to be $D$. viscosa subsp angustifolia. Therefore, a revision of the taxonomic classification is recommended as the Narok and Nairobi collections had no relatedness with Nanyuki and Machakos plants that are all currently regarded as subspecies angustifolia. Further characterization of these populations is needed and a molecular phylogenetic analysis would provide new insights into the taxonomy of D. viscosa in Kenya. From the four compounds isolated (two diterpenoids and two flavonoids), hautriwaic acid lactone (3), and catechin (4) were the most active in terms of antimicrobial activity. This is the first report on the isolation of $5,7,4^{\prime}, 5^{\prime}$-tetrahydroxy-3,6,2'-trimethoxyflavone (2) from this species. We also recommend studies of different pharmacological activities (both in vitro and in vivo) to determine whether the $D$. viscosa populations are different in terms of their bioactivity. 
Supplementary Materials: The following are available online at http://www.mdpi.com/1420-3049/25/18/4130/s1, Table S1: ${ }^{1} \mathrm{H}(500 \mathrm{MHz}),{ }^{13} \mathrm{C}(125 \mathrm{MHz}) \mathrm{NMR}$ data along with $\mathrm{HMBC}$ correlations $\left(\right.$ in $\left.\mathrm{CD}_{2} \mathrm{Cl}_{2}\right)$ for dodonic acid (1), Table S2: ${ }^{1} \mathrm{H}(500 \mathrm{MHz}),{ }^{13} \mathrm{C}(125 \mathrm{MHz}) \mathrm{NMR}$ data along with $\mathrm{HMBC}$ correlations (in $\left.\mathrm{CD}_{2} \mathrm{Cl}_{2}\right)$ for 5,7, $4^{\prime}, 5^{\prime}$-tetrahydroxy-3,6,2' -trimethoxyflavone (2), Table S3: ${ }^{1} \mathrm{H}(500 \mathrm{MHz}),{ }^{13} \mathrm{C}(125 \mathrm{MHz}) \mathrm{NMR}$ data along with HMBC correlations (in $\mathrm{CDCl}_{3}$ ) for hautriwaic acid lactone (3), Table S4: ${ }^{1} \mathrm{H}(500 \mathrm{MHz}),{ }^{13} \mathrm{C}(125 \mathrm{MHz}) \mathrm{NMR}$ data along with $\mathrm{HMBC}$ correlations (in $\mathrm{CD}_{3} \mathrm{OD}$ ) for catechin (4), Figure S1: Chemical structures of compounds 1-4 isolated from coastal plants of D. viscosa, Figure S2. The ${ }^{1} \mathrm{H}-\mathrm{NMR}$ spectrum of dodonic acid (1) observed at $500 \mathrm{MHz}$ in $\mathrm{CD}_{2} \mathrm{Cl}_{2}$ solution at $25{ }^{\circ} \mathrm{C}$, Figure S3. The ${ }^{13} \mathrm{C}-\mathrm{NMR}$ spectrum of dodonic acid (1) observed at 500 $\mathrm{MHz}$ in $\mathrm{CD}_{2} \mathrm{Cl}_{2}$ solution at $25^{\circ} \mathrm{C}$, Figure $\mathrm{S} 4$. The ${ }^{1} \mathrm{H}-{ }^{1} \mathrm{H}-\mathrm{COSY}-\mathrm{NMR}$ spectrum of dodonic acid (1) observed at $500 \mathrm{MHz}$ in $\mathrm{CD}_{2} \mathrm{Cl}_{2}$ solution at $25^{\circ} \mathrm{C}$, Figure S5. The ${ }^{1} \mathrm{H}^{13} \mathrm{C}-\mathrm{HSQC}-\mathrm{NMR}$ spectrum of dodonic acid (1) observed at $500 \mathrm{MHz}$ in $\mathrm{CD}_{2} \mathrm{Cl}_{2}$ solution at $25^{\circ} \mathrm{C}$, Figure S6. The ${ }^{1} \mathrm{H}-{ }^{13} \mathrm{C}-\mathrm{HMBC}-\mathrm{NMR}$ spectrum of dodonic acid (1) observed at $500 \mathrm{MHz}$ in $\mathrm{CD}_{2} \mathrm{Cl}_{2}$ solution at $25^{\circ} \mathrm{C}$, Figure S7. ESIMS spectrum for dodonic acid (1), Figure S8. The ${ }^{1} \mathrm{H}-\mathrm{NMR}$ spectrum of $5,7,4^{\prime}, 5^{\prime}$-tetrahydroxy-3,6,2' -trimethoxyflavone (2) observed at $500 \mathrm{MHz}$ in $\mathrm{CD}_{2} \mathrm{Cl}_{2}$ solution at $25^{\circ} \mathrm{C}$, Figure S9. ${ }^{13} \mathrm{C}$-NMR spectrum of 5,7,4', $5^{\prime}$-tetrahydroxy-3,6,2'-trimethoxyflavone (2) observed at $500 \mathrm{MHz}$ in $\mathrm{CD}_{2} \mathrm{Cl}_{2}$ solution at $25{ }^{\circ} \mathrm{C}$, Figure $\mathrm{S} 10 .{ }^{1} \mathrm{H}-{ }^{13} \mathrm{C}$-HSQC spectrum of $5,7,4^{\prime}, 5^{\prime}$-tetrahydroxy-3,6,2' -trimethoxyflavone (2) observed at $500 \mathrm{MHz}$ in $\mathrm{CD}_{2} \mathrm{Cl}_{2}$ solution at $25{ }^{\circ} \mathrm{C}$, Figure $\mathrm{S} 11 .{ }^{1} \mathrm{H}-{ }^{13} \mathrm{C}-\mathrm{HMBC}$ spectrum of $5,7,4^{\prime}, 5^{\prime}$-tetrahydroxy-3,6,2'-trimethoxyflavone (2) observed at $500 \mathrm{MHz}$ in $\mathrm{CD}_{2} \mathrm{C}_{12}$ solution at $25^{\circ} \mathrm{C}$, Figure $\mathrm{S} 12$. ESIMS spectrum for 5,7,4', $5^{\prime}$-tetrahydroxy-3,6,2'-trimethoxyflavone (2), Figure S13. The ${ }^{1} \mathrm{H}-\mathrm{NMR}$ spectrum of hautriwaic acid lactone (3) observed at $500 \mathrm{MHz}$ in $\mathrm{CDCl}_{3}$ solution at $25{ }^{\circ} \mathrm{C}$, Figure S14. ${ }^{13} \mathrm{C}-\mathrm{NMR}$ spectrum of hautriwaic acid lactone (3) observed at $500 \mathrm{MHz}$. in $\mathrm{CDCl}_{3}$ solution at $25{ }^{\circ} \mathrm{C}$, Figure S15. The ${ }^{1} \mathrm{H}-{ }^{1} \mathrm{H}-\mathrm{COSY}-\mathrm{NMR}$ spectrum of hautriwaic acid lactone (3) observed at $500 \mathrm{MHz}$ in $\mathrm{CDCl}_{3}$ solution at $25^{\circ} \mathrm{C}$, Figure S16. The ${ }^{1} \mathrm{H}_{-}{ }^{13} \mathrm{C}-\mathrm{HSQS}$ NMR spectrum of hautriwaic acid lactone (3) observed at $500 \mathrm{MHz}$ in $\mathrm{CDCl}_{3}$ solution at $25{ }^{\circ} \mathrm{C}$, Figure S17. The ${ }^{1} \mathrm{H}_{-}{ }^{13} \mathrm{C}-\mathrm{HMBC}$ NMR spectrum of hautriwaic acid lactone (3) observed at 500 $\mathrm{MHz}$ in $\mathrm{CDCl}^{3}$ solution at $25^{\circ} \mathrm{C}$, Figure S18. ESIMS for hautriwaic acid lactone (3), Figure S19. The ${ }^{1} \mathrm{H}-\mathrm{NMR}$ spectrum of catechin (4) observed at $500 \mathrm{MHz}$ in MeOD solution at $25^{\circ} \mathrm{C}$, Figure S20. The ${ }^{13} \mathrm{C}-\mathrm{NMR}$ spectrum of catechin (4) observed at $500 \mathrm{MHz}$ in MeOD solution at $25^{\circ} \mathrm{C}$, Figure S21. The ${ }^{1} \mathrm{H}-{ }^{1} \mathrm{H}-\mathrm{COSY}$ spectrum of catechin (4) observed at $500 \mathrm{MHz}$ in MeOD solution at $25^{\circ} \mathrm{C}$, Figure S22. The ${ }^{1} \mathrm{H}-{ }^{13} \mathrm{C}-\mathrm{HSQC}-\mathrm{NMR}$ spectrum of catechin (4) observed at $500 \mathrm{MHz}$ in MeOD solution at $25^{\circ} \mathrm{C}$, Figure S23. The ${ }^{1} \mathrm{H}-{ }^{13} \mathrm{C}-\mathrm{HMBC}-\mathrm{NMR}$ spectrum of catechin (4) observed at 500 and $125 \mathrm{MHz}$ in MeOD solution at $25^{\circ} \mathrm{C}$, Figure S24. ESIMS for catechin (4), Figure S25. Random permutation of discriminant chemicals for the five populations of D. viscosa in Kenya, Figure S26. k-fold cross-validation of discriminant chemicals for the five populations of D. viscosa in Kenya.

Author Contributions: N.P.M. and C.W.L. conceptualized the idea; C.W.L. was responsible for the botanical aspects of the project, sample collection and identification; M.M.K., N.P.M., and M.T. were responsible for the sample extraction; LCMS analysis and data processing; M.M.K. and N.P.M. were responsible for the multivariate data analysis and interpretation; M.M.K. and A.Y. were involved in phytochemical isolation and compound characterization; P.J.O. and A.Y. participated in structure determination of the pure compounds; M.M.K. wrote the first draft of the manuscript. All authors have read and agreed to the published version of the manuscript.

Funding: This research received funding from the National Research Foundation (NRF) of South Africa as an award to N.P.M. and the N.R.F. of Kenya as an award to C.L.M. (under the Kenya-South Africa bilateral research program; grant number 105810) and International Science Program-Sweden (KEN 02 project) awarded to A.Y.

Acknowledgments: Mizpah Hoffman is appreciated for her guidance regarding the multivariate analysis. Mathias Heydenreich of the University of Potsdam, Germany and Jaco Brand of the Central Analytical Facility, Stellenbosch University are thanked for carrying out the high-resolution NMR analysis of the isolated compounds.

Conflicts of Interest: The authors declare no conflict of interest.

\section{References}

1. Makunga, N.P.; Engelbrecht, A.M. Method and Composition for Treating Breast Cancer. Google Patents 0,188,689, 29 January 2019.

2. Anandan, M.; Prabu, H.G. Dodonaea viscosa leaf extract assisted synthesis of gold nanoparticles: Characterization and cytotoxicity against A549 NSCLC cancer cells. J. Inorg. Organomet Polym. Mater. 2018, 28, 932-941. [CrossRef]

3. Venkatesh, S.; Reddy, Y.S.R.; Ramesh, M.; Swamy, M.M.; Mahadevan, N.; Suresh, B. Pharmacognostical studies on Dodonaea viscosa leaves. African J. Pharm. Pharmacol. 2008, 2, 83-88.

4. Tauchen, J.; Doskocil, I.; Caffi, C.; Lulekal, E.; Marsik, P.; Havlik, J.; Van Damme, P.; Kokoska, L. In vitro antioxidant and anti-proliferative activity of Ethiopian medicinal plant extracts. Ind. Crops Prod. 2015, 74, 671-679. [CrossRef] 
5. Rojas, A.; Cruz, S.; Ponce-Monter, H.; Mata, R. Smooth muscle relaxing compounds from Dodonaea viscosa. Planta. Med. 1996, 62, 154-159. [CrossRef]

6. Getie, M.; Gebre-Mariam, T.; Rietz, R.; Höhne, C.; Huschka, C.; Schmidtke, M.; Abate, A.; Neubert, R.H. Evaluation of the anti-microbial and anti-inflammatory activities of the medicinal plants Dodonaea viscosa, Rumex nervosus and Rumex abyssinicus. Fitoterapia 2003, 74, 139-143. [CrossRef]

7. Khalil, N.M.; Sperotto, J.S.; Manfron, M.P. Antiinflammatory activity and acute toxicity of Dodonaea viscosa. Fitoterapia 2006, 77, 478-480. [CrossRef]

8. Al-Snafi, A.E. A review on Dodonaea viscosa: A potential medicinal plant. IOSR J. Pharm. 2017, 7, 10-21. [CrossRef]

9. Rani, M.S.; Pippalla, R.S.; Mohan, K. Dodonaea viscosa Linn.-An overview. Asian J. Pharm. Res. Heal. Care. 2009, 1, 97-112.

10. Mostafa, A.E.; Atef, A.; Mohammad, A.E.; Jacob, M.; Cutler, S.J.; Ross, S.A. New secondary metabolites from Dodonaea viscosa. Phytochem. Lett. 2014, 8, 10-15. [CrossRef]

11. Muhammad, A.; Tel-Cayan, G.; Öztürk, M.; Nadeem, S.; Duru, M.E.; Anis, I.; Ng, S.W.; Shah, M.R. Biologically active flavonoids from Dodonaea viscosa and their structure-activity relationships. Ind. Crops Prod. 2015, 78, 66-72. [CrossRef]

12. Harrington, M.G.; Gadek, P.A. A species well travelled-the Dodonaea viscosa (Sapindaceae) complex based on phylogenetic analyses of nuclear ribosomal ITS and ETSf sequences. J. Biogeogr. 2009, 36, 2313-2323. [CrossRef]

13. Christmas, M.J.; Biffin, E.; Lowe, A.J. Transcriptome sequencing, annotation and polymorphism detection in the hop bush, Dodonaea viscosa. BMC Genom. 2015, 16, 803. [CrossRef] [PubMed]

14. Beentje, H.; Adamson, J.; Bhanderi, D. Kenya Trees, Shrubs, and Lianas; National Museums of Kenya: Nairobi, Kenya, 1994.

15. Kindt, R.; Groen, T.; de Leeuw, J.; Lilleso, J.P. Distribution and ecology of trees in Eastern Africa drylands. In Treesilience: An Assessment of the Resilience Provided by Trees in the Drylands of Eastern Africa; de Leeuw, J., Ed.; The World Agroforestry Centre (ICRAF): Nairobi, Kenya, 2014; pp. 24-34.

16. Omosa, L.K.; Midiwo, J.O.; Derese, S.; Yenesew, A.; Peter, M.G.; Heydenreich, M. neo-Clerodane diterpenoids from the leaf exudate of Dodonaea angustifolia. Phytochem. Lett. 2010, 3, 217-220. [CrossRef]

17. Omosa, L.K.; Amugune, B.; Ndunda, B.; Milugo, T.K.; Heydenreich, M.; Yenesew, A.; Midiwo, J.O. Antimicrobial flavonoids and diterpenoids from Dodonaea angustifolia. South. Afr. J. Bot. 2014, 91, 58-62. [CrossRef]

18. Martucci, M.E.P.; De Vos, R.C.H.; Carollo, C.A.; Gobbo-Neto, L. Metabolomics as a potential chemotaxonomical tool: Application in the genus Vernonia Schreb. PLoS ONE 2014, 9, e93149. [CrossRef]

19. Sandasi, M.; Kamatou, G.P.P.; Viljoen, A.M. An untargeted metabolomic approach in the chemotaxonomic assessment of two Salvia species as a potential source of $\alpha$-bisabolol. Phytochemistry 2012, 84, 94-101. [CrossRef]

20. Padilla-González, G.F.; Diazgranados, M.; Da Costa, F.B. Biogeography shaped the metabolome of the genus Espeletia: A phytochemical perspective on an Andean adaptive radiation. Sci. Rep. 2017, 7, 8835. [CrossRef]

21. Chagas-Paula, D.A.; Oliveira, T.B.; Zhang, T.; Edrada-Ebel, R.; Da Costa, F.B. Prediction of anti-inflammatory plants and discovery of their biomarkers by machine learning algorithms and metabolomic studies. Planta. Med. 2015, 81, 450-458. [CrossRef]

22. Cox, D.G.; Oh, J.; Keasling, A.; Colson, K.L.; Hamann, M.T. The utility of metabolomics in natural product and biomarker characterization. Biochim. Biophys. Acta. (BBA)-Gen. Subj. 2014, 1840, 3460-3474. [CrossRef]

23. Albrecht, C.F.; Stander, M.A.; Grobbelaar, M.C.; Colling, J.; Kossmann, J.; Hills, P.N.; Makunga, N.P. LC-MS-based metabolomics assists with quality assessment and traceability of wild and cultivated plants of Sutherlandia frutescens (Fabaceae). South Afr. J. Bot. 2012, 82, 33-45. [CrossRef]

24. Yuliana, N.D.; Jahangir, M.; Verpoorte, R.; Choi, Y.H. Metabolomics for the rapid dereplication of bioactive compounds from natural sources. Phytochem. Rev. 2013, 12, 293-304. [CrossRef]

25. Niu, H.M.; Zeng, D.Q.; Long, C.L.; Peng, Y.H.; Wang, Y.H.; Luo, J.F.; Wang, H.S.; Shi, Y.N.; Tang, G.H.; Zhao, F.W. Clerodane diterpenoids and prenylated flavonoids from Dodonaea viscosa. J. Asian Nat. Prod. Res. 2010, 12, 7-14. [CrossRef] [PubMed]

26. Dreyer, D.L. Kaempferol methyl ethers from flowers of Dodonaea viscosa. Rev. Lat. Am. Quim. 1978, 9, 97-98. 
27. Hamadi, S.S. Chemical study of Dodonaea viscosa planting in Iraq. Int. J. Adv. Chem. Eng. Biol. Sci. 2017, 4, 121-125.

28. de Oliveira, S.Q.; de Almeida, M.T.R.; Maraslis, F.; Silva, I.T.; Sincero, T.C.M.; Palermo, J.A.; Cabrera, G.M.; Caro, M.S.; Simões, C.M.; Schenkel, E.P. Isolation of three new ent-labdane diterpenes from Dodonaea viscosa Jacquin (Sapindaceae): Preliminary evaluation of antiherpes activity. Phytochem. Lett. 2012, 5, 500-505. [CrossRef]

29. Manjulatha, K. A Comparative Study of Different Parts of Flavonoid Rich Plant, Dodonaea Viscosa for Antimicrobial and Antioxidant Potential; Lambert Academic Publishing: Rīgā, Latvia, 2012. Available online: https//wwwlappublishingcom/catalog/details//store/gb/book/978-3-659-28793-0/Dodonaea-viscosaflavonoid-rich-plantand-its-biological-potential (accessed on 28 April 2020).

30. Wiklund, S. Multivariate Data Analysis for Omics; Umea Umetrics: Umeå, Sweden, 2008.

31. Barton, N.H. The role of hybridization in evolution. Mol. Ecol. 2001, 10, 551-568. [CrossRef]

32. Boccard, J.; Rutledge, D.N. A consensus orthogonal partial least squares discriminant analysis (OPLS-DA) strategy for multiblock Omics data fusion. Anal. Chim. Acta. 2013, 769, 30-39. [CrossRef]

33. Kooke, R.; Keurentjes, J.J.B. Epigenetic variation contributes to environmental adaptation of Arabidopsis thaliana. Plant Signal. Behav. 2015, 10, e1057368. [CrossRef]

34. Verma, N.; Shukla, S. Impact of various factors responsible for fluctuation in plant secondary metabolites. J. Appl. Res. Med. Aromat. Plants 2015, 2, 105-113. [CrossRef]

35. Newman, D.J.; Cragg, G.M. Natural products as sources of new drugs over the last 25 years. J. Nat. Prod. 2007, 70, 461-477. [CrossRef]

36. Mazid, M.; Khan, T.A.; Mohammad, F. Role of secondary metabolites in defense mechanisms of plants. Biol. Med. 2011, 3, 232-249.

37. Speranza, C.I. Drought coping and adaptation strategies: Understanding adaptations to climate change in agro-pastoral livestock production in Makueni district, Kenya. Eur. J. Dev. Res. 2010, 22, 623-642. [CrossRef]

38. Bhattacharjee, S. Reactive oxygen species and oxidative burst: Roles in stress, senescence and signal transducation in plants. Curr. Sci. 2005, 1113-1121.

39. Akula, R.; Ravishankar, G.A. Influence of abiotic stress signals on secondary metabolites in plants. Plant Signal. Behav. 2011, 6, 1720-1731. [CrossRef] [PubMed]

40. Smirnoff, N.; Stewart, G.R. Stress metabolites and their role in coastal plants. In Ecology of Coastal Vegetation; Springer: Haamstede, The Netherlands, 1985; pp. 273-278.

41. Christmas, M.J. Assessing Genomic Variation in the Hopbush, Dodonaea viscosa, to Investigate Micro-Evolution and Adaptation. Ph.D. Thesis, The University of Adelaide, Adelaide, South Australia, December 2016.

42. Yu, S.; Fang, N.; Mabry, T.J. Flavonoids from Gymnosperma glutinosum. Phytochemistry 1988, 27, $171-177$. [CrossRef]

43. Sachdev, K.; Kulshreshtha, D.K. Flavonoids from Dodonaea viscosa. Phytochemistry 1983, 22, $1253-1256$. [CrossRef]

44. Compean, K.L.; Ynalvez, R.A. Antimicrobial activity of plant secondary metabolites: A review. Res. J. Med. Plants 2014, 8, 204-213.

45. Tiwari, R.; Rana, C.S. Plant secondary metabolites: A review. Int. J. Eng. Res. Gen. Sci. 2015, 3, 661-670.

46. Pirzada, A.J.; Shaikh, W.; Usmanghani, K.; Mohiuddin, E. Antifungal activity of Dodonaea viscosa Jacq extract on pathogenic fungi isolated from super ficial skin infection. Pak. J. Pharm. Sci. 2010, 23, 337-340.

47. Ramamurthy, V.; Rajeswari, D.M.; Gowri, R.; Vadivazhagi, M.K.; Jayanthi, G.; Raveendran, S. Study of the phytochemical analysis and antimicrobial activity of Dodonaea viscosa. J. Pure Appl. Zool. 2013, 1, 178-184.

48. Naidoo, R.; Patel, M.; Gulube, Z.; Fenyvesi, I. Inhibitory activity of Dodonaea viscosa var. angustifolia extract against Streptococcus mutans and its biofilm. J. Ethnopharmacol. 2012, 144, 171-174. [CrossRef] [PubMed]

49. Rajamanickam, V.; Rajasekaran, A.; Anandarajagopal, K.; Sridharan, D.; Selvakumar, K.; Rathinaraj, B.S. Anti-diarrheal activity of Dodonaea viscosa root extracts. Int. J. Pharma. Bio. Sci. 2010, 1, 182-185.

50. Kabouche, A.; Kabouche, Z.; Öztürk, M.; Kolak, U.; Topçu, G. Antioxidant abietane diterpenoids from Salvia barrelieri. Food Chem. 2007, 102, 1281-1287. [CrossRef]

51. Dickson, R.A.; Houghton, P.J.; Hylands, P.J. Antibacterial and antioxidant cassane diterpenoids from Caesalpinia benthamiana. Phytochemistry 2007, 68, 1436-1441. [CrossRef] [PubMed]

52. Neerman, M.F. Sesquiterpene lactones: A diverse class of compounds found in essential oils possessing antibacterial and antifungal properties. Int. J. Aromather. 2003, 13, 114-120. [CrossRef] 
53. Srivastava, J.K.; Gupta, S. Extraction, characterization, stability and biological activity of flavonoids isolated from chamomile flowers. Mol. Cell. Pharmacol. 2009, 1, 138. [CrossRef]

54. Braca, A.; Sortino, C.; Politi, M.; Morelli, I.; Mendez, J. Antioxidant activity of flavonoids from Licania licaniaeflora. J. Ethnopharmacol. 2002, 79, 379-381. [CrossRef]

55. Veluri, R.; Weir, T.L.; Bais, H.P.; Stermitz, F.R.; Vivanco, J.M. Phytotoxic and antimicrobial activities of catechin derivatives. J. Agric. Food Chem. 2004, 52, 1077-1082. [CrossRef]

56. Bais, H.P.; Walker, T.S.; Stermitz, F.R.; Hufbauer, R.A.; Vivanco, J.M. Enantiomeric-dependent phytotoxic and antimicrobial activity of $( \pm)$-catechin. A rhizosecreted racemic mixture from spotted knapweed. Plant Physiol. 2002, 128, 1173-1179. [CrossRef]

57. Muthuswamy, S.; Rupasinghe, H.P.V. Fruit phenolics as natural antimicrobial agents: Selective antimicrobial activity of catechin, chlorogenic acid and phloridzin. J. Food Agric. Environ. 2005, 5, 81-85.

58. Xie, Y.; Yang, W.; Tang, F.; Chen, X.; Ren, L. Antibacterial activities of flavonoids: Structure-activity relationship and mechanism. Curr. Med. Chem. 2015, 22, 132-149. [CrossRef] [PubMed]

59. Wayne, P.A. Reference method for broth dilution antifungal susceptibility testing of yeasts, approved standard. CLSI Doc. 2002, M27-A2.

60. Wikler, M.A. Methods for dilution antimicrobial susceptibility tests for bacteria that grow aerobically: Approved standard. CLSI 2006, 26, M7-A7.

61. Balouiri, M.; Sadiki, M.; Ibnsouda, S.K. Methods for in vitro evaluating antimicrobial activity: A review. J. Pharm. Anal. 2016, 6, 71-79. [CrossRef]

62. Goodacre, R.; Broadhurst, D.; Smilde, A.K.; Kristal, B.S.; Baker, J.D.; Beger, R.; Bessant, C.; Connor, S.; Capuani, G.; Craig, A.; et al. Proposed minimum reporting standards for data analysis in metabolomics. Metabolomics 2007, 3, 231-241. [CrossRef]

63. Heyman, H.M.; Meyer, J.J.M. NMR-based metabolomics as a quality control tool for herbal products. South. Afr. J. Bot. 2012, 82, 21-32. [CrossRef]

64. Carazzone, C.; Mascherpa, D.; Gazzani, G.; Papetti, A. Identification of phenolic constituents in red chicory salads (Cichorium intybus) by high-performance liquid chromatography with diode array detection and electrospray ionisation tandem mass spectrometry. Food Chem. 2013, 138, 1062-1071. [CrossRef]

Sample Availability: Samples of the compounds (1-4) are available from the authors.

(C) 2020 by the authors. Licensee MDPI, Basel, Switzerland. This article is an open access article distributed under the terms and conditions of the Creative Commons Attribution (CC BY) license (http://creativecommons.org/licenses/by/4.0/). 